\title{
Revisão taxonômica das espécies brasileiras de abelhas do gênero Lestrimelitta Friese (Hymenoptera, Apidae, Meliponina) ${ }^{1}$
}

\author{
Paola Marchi ${ }^{2,3}$ \& Gabriel A. R. Melo ${ }^{2,4}$
}

${ }^{1}$ Contribuição número 1550 do Departamento de Zoologia, Universidade Federal do Paraná.

${ }^{2}$ Departamento de Zoologia, Universidade Federal do Paraná, Caixa Postal 19020, 81531-990 Curitiba-PR, Brasil.

${ }^{3}$ Programa de Pós-Graduação em Entomologia. Bolsista do CNPq. paola@ufpr.br

${ }^{4}$ Pesquisador do CNPq. garmelo@ufpr.br

\begin{abstract}
Taxonomic revision of the Brazilian species of the bee genus Lestrimelitta Friese (Hymenoptera, Apidae, Meliponina). The species of Lestrimelitta present in Brazil are revised. Fourteen species are recognized, six of them described as new: L. ciliata. sp. nov., L. maracaia $\mathbf{s p . ~ n o v . , ~ L . ~ s i m i l i s ~ s p . ~ n o v . , ~ L . ~ s p i n o s a ~} \mathbf{s p .}$ nov., L. sulina. sp. nov. and L. tropica sp. nov. The main morphological characters used to distinguish the species are pubescence, shape of the propodeal spiracle, the interorbital distances and size of the midtibial spurs. Lectotypes for Trigona (Lestrimelitta) rufa Friese, 1903 and Trigona (Lestrimelitta) rufipes Friese, 1903 are designated and redescribed. The male of L. limao (Smith, 1863 ) is described for the first time. The following additional valid species are diagnosed and their distinctive characters presented: L. ehrhardti Friese, 1931; L. glaberrima Oliveira \& Marchi, 2005; L.glabrata Camargo \& Moure, $1989 ;$ L. monodonta Camargo \& Moure, 1989 and L. nana Melo, 2003. Identification keys for workers and males, maps of geographic records and illustrations are presented.
\end{abstract}

KEYWORDS. Apoidea; cleptobiotic stingless-bees; Neotropical; new species.

RESUMO. Revisão taxonômica das espécies de abelhas do gênero Lestrimelitta Friese (Hymenoptera, Apidae, Meliponina) que ocorrem no Brasil. Com base em caracteres morfológicos, como aqueles relacionados com a pilosidade, o formato do espiráculo propodeal, as distâncias interorbitais e o comprimento do esporão mesotibial, são reconhecidas catorze espécies, seis das quais novas para a Ciência: L. ciliata. sp. nov., L. maracaia sp. nov., L. similis sp. nov., L. spinosa $\mathbf{s p .}$ nov., L sulina. sp. nov. e L. tropica sp. nov. São designados lectótipos para Trigona (Lestrimelitta) limao var. rufipes Friese, 1903 e Trigona (Lestrimelitta) limao var. rufa Friese, 1903. O macho de L. limao (Smith, 1863) é descrito pela primeira vez. É apresentada também uma diagnose das seguintes espécies: L. ehrhardti Friese, 1931; L. glaberrima Oliveira \& Marchi, 2005; L. glabrata Camargo \& Moure, 1989; L. monodonta Camargo \& Moure, 1989; e L. nana Melo, 2003. São apresentados chaves de identificação para operárias e machos, ilustrações e mapas de ocorrência.

PALAVRAS-CHAVE. Abelhas cleptobióticas; Apoidea; Neotropical; espécies novas.

Entre os gêneros de meliponíneos reconhecidos para a região Neotropical, Lestrimelitta destaca-se por conter apenas formas cleptobióticas. Além de Lestrimelitta, o comportamento cleptobiótico obrigatório é conhecido apenas para Cleptotrigona e possivelmente Trichotrigona. As evidências disponíveis indicam que tal comportamento evoluiu independentemente nos três grupos (Michener 1990; Camargo $\&$ Pedro 2003). Essas abelhas não coletam pólen nem néctar nas flores, mas roubam de outras colônias de Meliponina (Sakagami \& Laroca 1963; Roubik 1989; Bego et al. 1991; Wittmann et al. 1990; Sakagami et al. 1993). Neste sentido, possivelmente como conseqüência da perda do comportamento de coletar e transportar pólen, as tíbias posteriores são desprovidas de corbícula, o rastelo é composto por pêlos curtos e finos e os basitarsos posteriores apresentam sua maior largura no terço basal (Schwarz 1948; Moure 1951; Michener 1990). Há evidências morfológicas e moleculares de que Lestrimelitta teria Plebeia como grupo-irmão (Michener 1990; Costa et al. 2003).

Friese (1903) propôs Lestrimelitta como novo subgênero de Trigona e distinguiu duas variedades: Trigona (Lestrimelitta) limao var. rufipes (baseando-se em uma série de operárias e machos de Bauru, SP, Brasil), e Trigona (Lestrimelitta) limao var. rufa (com base em 4 operárias de Rio Acre, Brasil). Posteriormente, em 1912, elevou esse táxon a gênero ao descrever L. cubiceps da África. Em 1931, descreveu L. ehrhardti (restrita ao território brasileiro).

Moure (1946), baseado na especialização etológica do grupo e na ausência de corbícula nas tíbias posteriores das operárias, destaca este gênero em tribo à parte, Lestrimelittini. Porém, Moure et al. (1958) retomam a classificação tradicional do grupo e suprimem o status de tribo para o grupo. Com relação às espécies africanas, Moure (1951), mesmo sem ter examinado exemplares do grupo, supõe que as diferenças apontadas na literatura poderiam sugerir para estas a criação de um gênero ou subgênero que traduzisse em termos sistemáticos tal divergência. Em 1961, propõe para estas espécies africanas um novo subgênero, Cleptotrigona.

O gênero Lestrimelitta foi revisado por Schwarz (1948), que reconheceu apenas duas espécies: L. ehrhardti Friese, 1931 e L. limao (Smith, 1863), embora indicasse algumas variações, principalmente na pilosidade, entre os exemplares reconhecidos como $L$. limao, em relação à sua ampla distribuição geográfica (do México à Argentina). Após a 
monografia de Schwarz (1948), o gênero não foi revisado novamente, tendo sido publicados apenas trabalhos isolados contendo descrições de táxons novos.

Os seguintes nomes foram propostos nesse período: $L$. guyanensis (Guiana Francesa), por Roubik (1980); L. monodonta (Brasil, Roraima) e L. glabrata (Brasil, Amazonas e Roraima) por Camargo \& Moure (1989); L. chamelensis e L. niitkib (ambas do México), por Ayala (1999); L. nana (Brasil, Amapá) por Melo (2003); L. danuncia (Costa Rica e Panamá), L. mourei (Costa Rica) e L. glaberrima (Guiana Francesa), por Oliveira \& Marchi (2005).

No presente trabalho, as espécies presentes no Brasil são diagnosticadas e discutidas taxonomicamente. Além do reconhecimento de oito espécies previamente descritas, são propostas seis novas espécies. Apresenta-se chave de identificação para operárias e machos. Embora sem registros para o Brasil, L. guyanensis Roubik, 1980 foi incluída na chave para operárias.

\section{MATERIAL E MÉTODOS}

A maioria dos espécimes estudados pertence à Coleção de Entomologia Pe. J. S. Moure, Departamento de Zoologia da Universidade Federal do Paraná, Curitiba, Brasil (DZUP). O material das seguintes instituições, seguidas pelo nome do pesquisador responsável, também foi examinado: AMNH: American Museum of Natural History (New York, Estados Unidos), Dr. Jerome G. Rozen, Jr.; BMNH: The Natural History Museum, Department of Entomology (British Museum, London), Mr. George Else; DMHN: Divisão de Museu de História Natural Capão da Imbuia (Curitiba, Paraná, Brasil), Solange Regina Malkowski; INPA: Instituto Nacional de Pesquisa da Amazônia (Manaus, Amazonas, Brasil), Dr. José Albertino Rafael; LEA: Laboratório de Estudos Sobre Abelhas, Departamento de Biologia, UFMA (São Luís, Maranhão, Brasil), Dr ${ }^{\mathrm{a}}$ Lenira Lacerda; MPEG: Museu Paraense Emilio Goeldi (Belém, Pará, Brasil), Dr. Orlando T. Silveira; RPSP: Coleção Camargo, Departamento de Biologia, Faculdade de Filosofia, Ciências e Letras de Ribeirão Preto-USP (Ribeirão Preto, São Paulo, Brasil), Dr. João M. F. de Camargo; SEMK: Snow Entomological Collection, University of Kansas Natural History Museum (Lawrence, KS, USA), Dr. Zack Falin; UFMG: Departamento de Zoologia da Universidade Federal de Minas Gerais (Belo Horizonte, Minas Gerais, Brasil), Dr. Fernando A. Silveira; ZMHB: Museum Für Naturkunde Der Humboldt Universitat zu Berlin (Berlin, Alemanha), Dr. Frank Koch.

A terminologia utilizada para o estudo morfológico foi baseada em Urban (1967); Camargo et al. (1967) e Michener (2000). Nas descrições foram utilizadas as abreviações: DP (diâmetro do ponto) e T (tergo). As mensurações referem-se aos holótipos. As medidas, quando não acompanhadas das unidades, são dadas em milímetros. O comprimento da asa anterior foi medido desde o ápice do esclerito Costal, até a extremidade da asa. A largura do mesossoma foi obtida entre as tégulas e do escutelo, no bordo anterior entre as axilas. $\mathrm{O}$ contorno da abertura do espiráculo propodeal, observado em vista látero-posterior foi considerado ovalado quando curto e largo, no máximo 3 vezes mais longo que largo ou alongado quando longo e estreito, aproximadamente 6 vezes mais longo que largo. O comprimento do esporão mesotibial, de acordo com Oliveira (2002), foi considerado como extremamente reduzido (não visível); reduzido (visível, em torno de $0,05 \mathrm{~mm}$ ); curto (em torno de $0,15 \mathrm{~mm}$ ) ou normal (em torno de $1 / 3$ do comprimento do basitarso médio). As variações observadas, principalmente no comprimento do esporão mesotibial, foram registradas.

$\mathrm{Na}$ listagem do 'Material examinado', os dados originais das etiquetas são inteiramente transcritos, cada etiqueta do exemplar indicada por aspas simples. Os dados sobre a ocorrência das espécies foram obtidos das etiquetas do material examinado e da literatura. As coordenadas geográficas aproximadas foram obtidas em sítios na internet: Getty Thesaurus of Geografic Names; Global Gazetter; IBGE. Os mapas foram gerados no programa Arcview Gis 3.2a. Foram também incluídos na listagem de material examinado e nos mapas os registros adicionais para outros países.

Nas listagens sinonímicas, são feitas referências apenas aos trabalhos tratando da sistemática do grupo.

\section{Lestrimelitta Friese}

Trigona (Lestrimelitta) Friese, 1903: 361. Espécie-tipo Trigona limao Smith, 1863.

Lestrimelitta; Friese (1912: 169); Ducke (1916: 29, 39); Friese (1931: 2, 10, 14); Schwarz (1932: 245, 246, 251); Schwarz (1938: 451); Moure (1946: 609-611); Schwarz (1948: 173-195); Moure (1951: 27, 29-31); Moure (1961: 183, 184, 219, 220); Lucas de Oliveira (1964: 35-39; 1968: 1); Wille (1979: 259); Roubik (1980: 263264); Almeida \& Laroca (1982: 41); Wille (1983: 41-45); Camargo \& Moure (1989:195-196); Michener (1990: 91, 95, 97-100, 102105, 117-118, 132); Michener \& Roubik (1993: 251, 253, 256, 262 Ayala (1999: 1, 25-32); Michener (2000: 779, 784-786, 791793); Oliveira (2002: 196-197); Silveira et al. (2002: 84, 87); Costa et al. (2003: 75, 77-80); Marchi \& Melo (2004: 379, 381).

Operárias. Asas anteriores ultrapassando um pouco o metassoma; hâmulos, 5-6; face externa das tíbias posteriores levemente convexa em toda extensão, corbícula e penicilo ausentes; rastelo composto por pêlos finos e curtos. Cabeça mais larga que longa e mais larga que o mesossoma; olhos aproximadamente 2 vezes mais longos que sua largura máxima, órbitas internas fracamente sinuosas; escapos longos e finos, aproximadamente 5,5 vezes mais longos que largos; $1^{\circ}$. flagelômero em torno de 2 vezes mais longo que $2^{\circ}$; clípeo curto, aproximadamente 3,5 vezes mais largo que longo, com bordo apical geralmente castanho-claro; labro com forte depressão longitudinal entre as laterais protuberantes; mandíbulas com base mais larga que ápice, um pouco aguçadas no ápice; genas mais largas que olhos em vista lateral; basitarsos médios 5-6 vezes mais longos que largos; basitarsos posteriores aproximadamente 3 vezes mais longos que largos; metassoma arredondado no ápice. Integumento, de modo geral acastanhado, liso e brilhante, com pontuação pilígera muito fina e pouco conspícua na cabeça, bastante esparsa nas regiões paroculares inferior e média, mais densa na porção superior da 
fronte e vértice; pontos maiores e mais esparsos nos mesepisternos. Pilosidade escassa, principalmente na cabeça, mesepisternos e metassoma; cabeça e mesossoma com micropilosidade decumbente não ramificada. Cerdas longas no bordo inferior das mandíbulas e labro; olhos praticamente glabros; metaposnoto glabro; algumas cerdas eretas compridas nos flancos do propódeo; tíbias anteriores e médias com cerdas eretas amareladas e curtas no bordo posterior e próximo ao ápice do bordo anterior; tíbias médias com micropilosidade decumbente mais longa e densa na face externa do que nas anteriores; tíbias posteriores cerca de 3 vezes mais longas do que sua largura máxima, com cerdas longas no bordo posterior e cerdas mais curtas no bordo anterior.

Machos. Semelhantes às operárias, exceto: cabeça menor e comprimento total do corpo maior; órbitas internas convergentes inferiormente; escapos aproximadamente 4,5 vezes mais longos que largos; $1^{\circ}$. flagelômero um pouco mais longo que o $2^{\circ}$.; área malar 2 a 3 vezes mais estreita que o diâmetro do escapo; basitarsos médios em torno de 7 a 8 vezes mais longos que largos; basitarsos posteriores aproximadamente 4 vezes mais longos que largos; tíbias posteriores com cerdas em toda a face externa.

Lestrimelitta pode ser separado de outros gêneros de meliponíneos presentes no Brasil pelos caracteres indicados na chave de Silveira et al. (2002), para operárias.

\section{Chave de identificação das espécies de Lestrimelitta do Brasil} Operárias

1. Abelhas muito pequenas e glabras (largura máxima da cabeça $1,58 \mathrm{~mm}$ ); órbitas internas convergentes inferiormente. Brasil: Amapá .................... L. nana Melo

Abelhas relativamente maiores (largura máxima da cabeça a partir de 2,00 mm); órbitas internas não convergentes inferiormente. 2

2. Espiráculo propodeal ovalado ( 2 a $3 x$ mais longo do que largo) (Fig. 1) .3

Espiráculo propodeal alongado (5 a $6 \mathrm{x}$ mais longo do que largo) (Fig. 2)

3. Vértice com cerdas eretas relativamente densas (Figs. 8, 10) e todo o mesoscuto uniformemente cerdoso (Figs. $24,27,28)$ ...4

Vértice com poucas cerdas eretas, muito curtas e finas, restritas à região interocelar (Figs. 7, 9); sem cerdas eretas no disco do mesoscuto (Figs. 23, 26) .... 6

4. Órbitas internas paralelas; cerdas do mesoscuto não esbranquiçadas nas pontas; mesepisternos totalmente cerdosos (Fig.12); pilosidade muito densa, com aparência tomentosa (integumento não visível) nos flancos do propódeo (Figs. 18, 24); cerdas eretas a partir das laterais de T2. Brasil: Acre, Rondônia, Mato Grosso. Equador..... L. rufa (Friese)

Órbitas internas levemente divergentes inferiormente; cerdas, principalmente do mesoscuto, esbranquiçadas nas pontas (Figs. 27, 28); laterais dos mesepisternos sem cerdas na metade superior (Figs.15, 16); pilosidade nos flancos do propódeo não encobrindo totalmente 0 integumento (Figs. 21, 22); apenas tergos apicais com cerdas ...... 5

5. Laterais dos mesepisternos com cerdas eretas a partir da metade inferior (Fig.15); flancos do propódeo com pilosidade curta, fina e esparsa (Fig. 21); esporão mesotibial extremamente reduzido (não visível); T1 a T5 praticamente glabros, cerdas apenas em T6. Brasil: Paraná, Santa Catarina, Rio Grande do Sul .....

L. sulina sp. nov.

Laterais dos mesepisternos com cerdas eretas apenas na parte ventral (Fig.16); flancos do propódeo com pilosidade ramificada e densa, mas não tomentosa (Fig.22); esporão mesotibial curto, porém visível $(0,10$ $\mathrm{mm}$ ); cerdas nas laterais de T5 e em T6. Brasil: Ceará, Bahia, Rio de Janeiro L. tropica sp. nov.

6. Laterais dos mesepisternos totalmente cerdosas; cerdas nas laterais de $\mathrm{T} 1$, se presentes, muito curtas $(0,05 \mathrm{~mm})$

Laterais dos mesepisternos com cerdas eretas longas apenas na porção ventral; cerdas nas laterais de $\mathrm{T} 1$ (em torno de $0,10 \mathrm{~mm}$ ) . 8

7. Laterais dos mesepisternos com cerdas eretas enegrecidas e espessas (Fig.14); pilosidade ramificada nos flancos do propódeo (Fig.20); laterais de T1 com poucas cerdas curtíssimas e esparsas. Brasil: Pará. Trinidad ...

L. spinosa sp. nov.

Laterais dos mesepisternos com cerdas eretas castanhas nos dois terços inferiores; flancos do propódeo com pilosidade ramificada apenas próximo ao espiráculo; ausência de cerdas nas laterais de T1. Brasil: Roraima, Amazonas L. maracaia sp. nov.

8. Bordo anterior do mesoscuto com cerdas mais longas nas laterais e algumas muito curtas na porção mediana; laterais dos mesepisternos com cerdas eretas curtíssimas nos dois terços superiores e cerdas eretas (em torno de $0,05 \mathrm{~mm}$ ) no terço inferior (Fig. 11). Brasil: Maranhão a São Paulo L. limao (Smith)

Cerdas eretas em todo o bordo anterior do mesoscuto; laterais dos mesepisternos com cerdas curtíssimas no terço superior e cerdas eretas mais longas $(0,10 \mathrm{~mm})$ nos dois terços inferiores. Brasil: Pará

L. ciliata $\mathbf{s p . ~ n o v . ~}$

9. Cabeça e mesossoma (exceto o escutelo) praticamente glabros; cerdas eretas, se presentes, apenas nas laterais do bordo anterior do mesoscuto ................................. 10

Cabeça com muitas cerdas eretas no vértice e/ou rebordo pré-occipital; mesoscuto com cerdas eretas pelo menos nas laterais do bordo anterior 
10. Largura máxima da cabeça em torno de $2,15 \mathrm{~mm}$; escutelo com poucas cerdas muito curtas (em torno de $0,10 \mathrm{~mm}$ ) apenas no bordo posterior; tíbias médias com cerdas curtas e esparsas no bordo posterior; metassoma com cerdas apenas nos tergos apicais. Brasil: Amapá. Guiana Francesa ................... L. glaberrima Oliveira \& Marchi Largura máxima da cabeça em torno de 2,60 mm; escutelo com cerdas longas, espessas e densas (entre 0,40 a $0,60 \mathrm{~mm}$ ) a partir da metade posterior; cerdas das tíbias médias longas e densas na face externa e no bordo posterior; metassoma com cerdas a partir das laterais de $\mathrm{T} 2$

11. Cerdas eretas longas $(0,20 \mathrm{~mm})$, enegrecidas e espessas nas laterais do bordo anterior do mesoscuto; esporão mesotibial reduzido; laterais do bordo posterior de T2 a T5 com cerdas longas $(0,25 \mathrm{~mm})$ enegrecidas e espessas. Guiana. Guiana Francesa

L. guyanensis Roubik

Bordo anterior do mesoscuto sem cerdas eretas; esporão mesotibial normal; metassoma cerdoso, cerdas curtas $(0,10 \mathrm{~mm})$, acastanhadas e finas nas laterais de T2, aumentando um pouco na densidade e comprimento em direção ao T6. Brasil: Roraima, Amazonas, Acre, Mato Grosso. Guiana L. glabrata Camargo \& Moure

12. Lobos pronotais e tégulas sem cerdas eretas (Fig. 13); tíbias médias sem cerdas eretas na face externa; laterais dos mesepisternos com cerdas eretas apenas na parte ventral; pilosidade curta, fina e esparsa nos flancos do propódeo (Fig. 25); esporão mesotibial curto ............ 13

Lobos pronotais e bordo anterior das tégulas com cerdas eretas longas; tíbias médias com cerdas eretas na face externa; laterais dos mesepisternos com cerdas eretas longas; pilosidade esbranquiçada ramificada e densa nos flancos do propódeo; esporão mesotibial reduzido ou normal. 14

13. Mesoscuto com cerdas eretas longas no bordo anterior e na parte mediana do terço anterior do disco (Fig. 25); metassoma com cerdas em torno de $0,12 \mathrm{~mm}$ a partir de T2. Brasil . L. rufipes (Friese)

Mesoscuto com cerdas eretas apenas nas laterais do bordo anterior; metassoma com cerdas muito curtas e esparsas em T3, cerdas mais longas, em torno de 0,10 $\mathrm{mm}$, a partir de T4. Brasil: Pará

L. similis $\mathbf{s p . ~ n o v . ~}$

14. Cerdas eretas em toda a cabeça e ao longo dos escapos; mancha amarelo-marfim nas áreas paroculares inferiores; dois dentes pequenos no bordo apical das mandíbulas; cerdas enegrecidas curtas na face externa das tíbias anteriores e médias; esporão mesotibial normal. Brasil: Minas Gerais, São Paulo, Paraná, Santa Catarina L. ehrhardti Friese

Cerdas decumbentes na cabeça, eretas apenas no vértice (atrás dos ocelos) e no rebordo pré-occipital; cerdas eretas apenas no ápice dos escapos; sem mancha amarelo-marfim nas áreas paroculares inferiores; apenas um dente forte no bordo interno das mandíbulas; tíbias anteriores e médias sem cerdas enegrecidas na face externa; esporão mesotibial reduzido. Brasil: Roraima, Amazonas, Pará, Maranhão

L. monodonta Camargo \& Moure

Machos

(Os machos de L. guyanensis, L. monodonta e L. nana são desconhecidos)

1. Espiráculo propodeal ovalado ( 2 a $3 x$ mais longo do que largo) (Fig. 1) .................................................................. 2

Espiráculo propodeal alongado (5 a 6x mais longo do que largo) (Fig. 2)

2. Vértice com cerdas eretas relativamente densas (Figs. 8, 10) e mesoscuto uniformemente cerdoso (Figs. 24, 27, 28)

Vértice com poucas cerdas eretas, muito curtas e finas, restritas à região interocelar (Figs. 7, 9); sem cerdas eretas no disco do mesoscuto (Figs. 23, 26) ............... 5

3. Pilosidade muito densa, com aparência tomentosa (integumento não visível) nos flancos do propódeo; metassoma com cerdas a partir das laterais de T2. Brasil: Acre, Rondônia, Mato Grosso. Equador

L. rufa (Friese)

Pilosidade dos flancos do propódeo não encobrindo totalmente o integumento; metassoma com cerdas apenas nos tergos apicais

4. Laterais dos mesepisternos totalmente cerdosas; pilosidade dos flancos do propódeo curta, fina e esparsa. Brasil: Paraná, Santa Catarina, Rio Grande do Sul ..................................................... L. sulina sp. nov.

Laterais dos mesepisternos com cerdas eretas apenas na parte ventral; flancos do propódeo com pilosidade longa e ramificada, mas não tomentosa. Brasil: Ceará, Bahia, Rio de Janeiro L. tropica sp. nov.

5. Laterais dos mesepisternos cerdosas (cerdas em torno de $0,10 \mathrm{~mm})$

Laterais dos mesepisternos com cerdas eretas a partir da metade inferior .....

6. Laterais de $\mathrm{T} 1$ com cerdas eretas finas e curtas $(0,05 \mathrm{~mm})$ e esparsas; esporão mesotibial extremamente reduzido. Brasil: Pará. Trinidad . L. spinosa sp. nov.

Laterais de T1 com cerdas em torno de 0,10 mm; esporão mesotibial reduzido (em torno de 0,05 mm). Brasil: Roraima, Amazonas L. maracaia $\mathbf{s p . ~ n o v . ~}$

7. Região interocelar e rebordo pré-occipital com poucas cerdas muito curtas; bordo anterior do mesoscuto com 
cerdas eretas apenas nas laterais; laterais dos mesepisternos com cerdas eretas apenas na parte ventral. Brasil: Maranhão a São Paulo ... L. limao (Smith)

Região interocelar e rebordo pré-occipital com algumas cerdas eretas; cerdas eretas em todo o bordo anterior do mesoscuto; laterais dos mesepisternos com cerdas eretas $(0,05 \mathrm{~mm})$ a partir da metade inferior. Brasil: Pará L. ciliata sp. nov.

8. Cabeça e mesossoma (exceto o escutelo) praticamente glabros; cerdas eretas, se presentes, apenas nas laterais do bordo anterior do mesoscuto; sem mancha amarelomarfim nas áreas paroculares inferiores ... 9

Cabeça e mesossoma totalmente cerdosos; com mancha amarelo-marfim nas áreas paroculares inferiores. Brasil: Minas Gerais, São Paulo, Paraná, Santa Catarina

L. ehrhardti Friese

9. Tíbias médias com cerdas longas e densas na face externa e bordo posterior; cerdas das tíbias médias e posteriores espatuladas no ápice ............................... 10

Tíbias médias com cerdas curtas $(0,10 \mathrm{~mm})$ e esparsas no bordo posterior e próximo ao ápice do bordo anterior; cerdas das tíbias médias e posteriores não espatuladas no ápice .. 11

10. Mesoscuto totalmente glabro; esporão mesotibial normal; metassoma com cerdas eretas $(0,10-0,20 \mathrm{~mm}) \mathrm{em} \mathrm{T} 2 \mathrm{e}$ cerdas na porção mediana a partir de T3. Brasil: Roraima, Amazonas, Acre. Guiana

L. glabrata Camargo \& Moure.

Laterais do bordo anterior do mesoscuto com algumas cerdas eretas (em torno de $0,12 \mathrm{~mm}$ ); esporão mesotibial curto; metassoma com cerdas curtíssimas $(0,05 \mathrm{~mm}) \mathrm{em}$ T2 e cerdas na porção mediana a partir de T4. Brasil: Pará L. similis $\mathbf{s p . ~ n o v . ~}$

11. Escutelo praticamente glabro; face externa das tíbias posteriores com poucas cerdas $(0,05-0,10 \mathrm{~mm})$ próximas ao ápice; metassoma com cerdas apenas nos tergos apicais, a partir das laterais de T5. Brasil: Amapá. Guiana Francesa .................... L. glaberrima Oliveira \& Marchi

Escutelo com cerdas eretas na metade posterior; face externa das tíbias posteriores com cerdas em torno de $0,20 \mathrm{~mm}$; metassoma com cerdas eretas a partir das laterais de T3. Brasil.......................... L. rufipes (Friese)

\section{Lestrimelitta ehrhardti Friese, 1931}

(Fig. 32)

Trigona ehrhardti Friese, 1931: 10 (nomen nudum).

Lestrimelitta ehrhardti Friese, 1931: 13. Síntipos operárias, Brasil: Minas Gerais, Uberaba (AMNH, ZMHB?; não examinados). Friese (1931: 14); Schwarz (1938: 451); Schwarz (1948: 191-195); Moure (1951: 30); Lucas de Oliveira (1964: 42-46; 1968: 9); Roubik (1980: 263); Almeida \& Laroca (1982: 41-45); Wille (1983: 61); Camargo \& Moure (1989: 196, 198, 203, 207-210); Michener \&
Roubik (1993: 256); Oliveira (2002: 197-198); Silveira et al. (2002: $88)$.

Diagnose e Comentários. Única espécie conhecida deste gênero com cerdas eretas longas em toda a cabeça e ao longo do escapo; facilmente reconhecida pelas manchas evidentes amarelo-marfim nas áreas paroculares inferiores e pelo metassoma castanho-ferrugíneo. Almeida \& Laroca (1982) redescreveram o macho de L. ehrhardti com base em um grande número de exemplares provenientes de uma colônia de Castro, PR, concluindo que o exemplar descrito por Schwarz (1948), apesar de danificado, efetivamente pertencia a $L$. ehrhardti. Figuras dos esternos e genitália dos machos de L. ehrhardti podem ser encontradas nesses dois trabalhos.

Operária. Comprimento total aproximado: $6,17 \mathrm{~mm}$; comprimento das asas anteriores: $4,80 \mathrm{~mm}$; largura da cabeça: 2,45 mm. Cabeça castanho-enegrecida; áreas paroculares inferiores até a tangente superior do alvéolo antenal amarelomarfim; clípeo e genas castanhos. Órbitas internas paralelas; área malar praticamente igual ao diâmetro do escapo $(0,13: 0,14)$. Cabeça com cerdas eretas castanhas de aproximadamente 0,08 $\mathrm{mm}$, um pouco mais curtas e esparsas nas áreas paroculares inferiores e clípeo, e mais longas, com até $0,18 \mathrm{~mm}$, no vértice; escapo com cerdas eretas de aproximadamente $0,05 \mathrm{~mm}$, um pouco mais espessas no ápice. Lobos pronotais com cerdas castanhas eretas e longas $(0,18 \mathrm{~mm})$ e pilosidade plumosa curta e amarelada no seu limite com os mesepisternos. Bordo anterior das tégulas com cerdas eretas castanhas de aproximadamente $0,15 \mathrm{~mm}$. Mesoscuto cerdoso, bordo anterior com cerdas castanhas de aproximadamente $0,25 \mathrm{~mm}$ nas laterais e um pouco mais curtas $(0,20 \mathrm{~mm})$ na porção mediana; cerdas eretas de $0,10 \mathrm{~mm}$ no disco. Escutelo com cerdas castanhas um pouco encurvadas para cima, em torno de $0,35 \mathrm{~mm}$ no bordo posterior e um pouco mais curtas no disco. Laterais dos mesepisternos com cerdas eretas castanhas de aproximadamente $0,14 \mathrm{~mm}$. Tíbias anteriores com algumas cerdas semi-decumbentes na face externa. Tíbias médias com cerdas enegrecidas semidecumbentes na face externa e cerdas castanho-amareladas de aproximadamente $0,12 \mathrm{~mm}$ nos bordos laterais e ápice; esporão mesotibial normal $(0,25 \mathrm{~mm})$. Fêmures posteriores com cerdas castanho-enegrecidas uniformes em toda a face externa. Tíbias posteriores com cerdas enegrecidas e espessas de até $0,30 \mathrm{~mm}$ no bordo posterior, algumas com uma ou duas ramificações na parte mediana da cerda; bordo anterior com cerdas um pouco mais esparsas de até $0,25 \mathrm{~mm}$. Flancos do propódeo com pilosidade esbranquiçada, ramificada e densa, porém não tomentosa; espiráculo propodeal alongado, 6 vezes mais longo do que largo $(0,31: 0,05)$. Metassoma castanhoferrugíneo com cerdas castanhas e longas $(0,16 \mathrm{~mm})$ a partir das laterais de $\mathrm{T} 1$.

Macho. Comprimento das asas anteriores: 4,9 mm; largura da cabeça: 2,62 $\mathrm{mm}$. Semelhante à operária, exceto as mandíbulas e extremidades dos escapos amarelados; órbitas internas convergentes inferiormente; área malar a metade do diâmetro do escapo $(0,08: 0,15)$; tíbias posteriores com cerdas longas e semi-decumbentes na face externa; algumas cerdas 
eretas bastante longas próximo ao bordo anterior do espiráculo propodeal.

Material examinado. BRASIL. Minas Gerais: 1 operária (DZUP), 'Belo Horizonte, M. Gerais, Brasil, VIII-1961, F. M. Oliveira'. Rio de Janeiro: 2 operárias (DZUP) 'Itatiaya, 76, Est. do Rio, 1-V-1932'. São Paulo: 3 operárias (DZUP), 'Brasil, São Paulo, Cunha, $1000 \mathrm{~m}$, 24. IV. 1988'; 1 operária (SEMK), 'São Paulo/SP, Itaim Bibi, Brasil, 21. X. 1988, Leg. I Alves Santos'; 2 operárias (AMNH), idem; 1 macho (AMNH) 'Brazil, S. Paulo, 1887', 'acc 35178' e 'Lestrimelitta ehrhardti Friese'. Paraná: 12 operárias e 2 machos (DZUP), 'CASTRO-PR, Brasil, VII 62, S. Laroca'. Santa Catarina: 4 operárias (DZUP) 'Rio do Têsto, Sta. Catarina, Brazil, May, 1953'; 3 operárias (AMNH), idem.

Distribuição: Espécie restrita ao sudeste e sul do Brasil (Fig. 32).

\section{Lestrimelitta glaberrima Oliveira \& Marchi, 2005}

(Fig. 29)

Lestrimelitta glaberrima Oliveira \& Marchi, 2005: 1. Holótipo operária, Guiana Francesa: Kourou (SEMK).

Diagnose e Comentários. Cabeça e mesossoma praticamente glabros, exceto o mesoscuto, com algumas cerdas muito curtas $(0,06 \mathrm{~mm})$ nas laterais do bordo anterior e o escutelo com poucas cerdas eretas curtas e esparsas (em torno de $0,10 \mathrm{~mm}$ ) apenas no bordo posterior. Espiráculo propodeal alongado. Tíbias médias com cerdas curtas (até $0,10 \mathrm{~mm}$ ) e esparsas no bordo posterior; esporão mesotibial normal. Fêmures posteriores com cerdas apenas próximas ao ápice da face externa. Tíbias posteriores com cerdas castanhoenegrecidas (em torno de $0,26 \mathrm{~mm}$ ) no bordo posterior e cerca de metade deste comprimento no bordo anterior. Metassoma com cerdas castanhas a partir das laterais posteriores de $\mathrm{T} 4$ (em torno de $0,07 \mathrm{~mm}$ ), um pouco mais longas em T5 $(0,10 \mathrm{~mm})$ e T6 com cerdas longas, espessas e densas (em torno de 0,18 $\mathrm{mm})$.

Difere de L. glabrata Camargo \& Moure e L. guyanensis Roubik pelo menor tamanho corporal (largura da cabeça em torno de 2,15 mm), escutelo com poucas cerdas muito curtas, restritas ao bordo posterior, tíbias médias sem cerdas eretas na face externa e metassoma com cerdas apenas nos tergos apicais. O macho desta espécie difere facilmente do macho de L. glabrata Camargo \& Moure e de L. rufipes (Friese) pelo escutelo praticamente glabro, face externa das tíbias posteriores com poucas cerdas curtas próximas ao ápice e metassoma com cerdas apenas nos tergos apicais (a partir das laterais de T5).

Material adicional examinado. BRASIL. Amapá: 3 machos (MPEG), 'Brasil, Amapá, Amapari, TUCANO-2, 8 a 10.XI-1993', 'Brasil, AP, W. França' e 'Armadilha Malaise'.

Distribuição geográfica: Aparentemente restrita ao norte do Amazonas (Fig. 29).

\section{Lestrimelitta glabrata Camargo \& Moure, 1989} (Fig. 32)
Lestrimelitta limao; Schwarz (1948: 183 [parte dos espécimes do 'Northwest District', Guiana]).

Lestrimelitta glabrata Camargo \& Moure, 1989: 196. Holótipo operária, Brasil: Roraima, Ig. Aliança, rio Branco (RPSP; não examinado). Camargo \& Moure (1989: 198, 203, 205, 209, 210); Oliveira (2002: 197); Silveira et al. (2002: 88).

Diagnose e Comentários. Cabeça e mesossoma, exceto o escutelo, praticamente glabros; distingue-se de L. guyanensis por não apresentar cerdas longas e espessas nas laterais do bordo anterior do mesoscuto e de L. nana pelo maior tamanho corporal, pela presença das cerdas longas e densas no bordo posterior das tíbias médias e pelo metassoma bastante cerdoso (cerdas a partir de T2). Os machos, assim como os machos de L. similis sp. nov., são facilmente reconhecidos pelas cerdas do bordo posterior das tíbias médias e posteriores, amareladas, longas, densas e espatuladas no ápice, além das cerdas longas e densas no metassoma. Difere do macho de L. similis sp. nov., pelo mesoscuto totalmente glabro, esporão mesotibial normal e pelo metassoma com cerdas eretas nas laterais de T2 e na porção mediana a partir de T3. Schwarz (1948: 183), referindose à variação na pilosidade em L. limao, chamou atenção para os espécimes da 'British Guiana', sem cerdas eretas no mesoscuto, que na verdade correspondem a L. glabrata (vide 'Material adicional examinado'). Camargo \& Moure (1989) ilustraram, para as operárias, a cabeça, dentes das mandíbulas e mesossoma, e para os machos, as pernas, esternos apicais e genitália.

Operária. Comprimento total aproximado: $7,35 \mathrm{~mm}$; comprimento das asas anteriores: $4,70 \mathrm{~mm}$; largura da cabeça: 2,60 mm. Integumento castanho-enegrecido; órbitas internas divergentes inferiormente; área malar igual ao diâmetro do escapo $(0,16: 0,16)$; algumas cerdas muito curtas no rebordo pré-occipital; cerdas conspícuas somente no ápice dos escapos. Lobos pronotais e tégulas sem cerdas eretas. Laterais dos mesepisternos com cerdas longas apenas na parte ventral. Escutelo com cerdas eretas amareladas e bastante longas $(0,55$ $\mathrm{mm}$ ) a partir da metade posterior. Flancos do propódeo com pilosidade muito curta, fina e esparsa; contorno da abertura do espiráculo propodeal alongado, 6 vezes mais longo do que largo $(0,31: 0,05)$. Bordo posterior das tíbias médias com cerdas amareladas, longas $(0,22 \mathrm{~mm})$ e muito densas (algumas com poucas ramificações curtas na sua parte mediana); no bordo anterior, cerdas mais curtas a partir da metade apical; esporão mesotibial normal. Bordo posterior das tíbias posteriores com cerdas amareladas muito longas $(0,35 \mathrm{~mm})$, algumas com uma ou duas ramificações curtas na parte mediana; no bordo anterior, cerdas com metade deste comprimento. Metassoma cerdoso, cerdas finas e amareladas a partir das laterais de T2 e cerdas finas, curtas e esparsas a partir do bordo posterior de T3, aumentando em comprimento e densidade até o ápice.

Macho. Comprimento total aproximado: $8,00 \mathrm{~mm}$; comprimento das asas anteriores: 4,68 $\mathrm{mm}$; largura da cabeça: $2,29 \mathrm{~mm}$. Integumento predominantemente castanhoenegrecido; clípeo, base das mandíbulas, áreas paroculares inferiores e face ventral dos escapos amarelados. Órbitas 

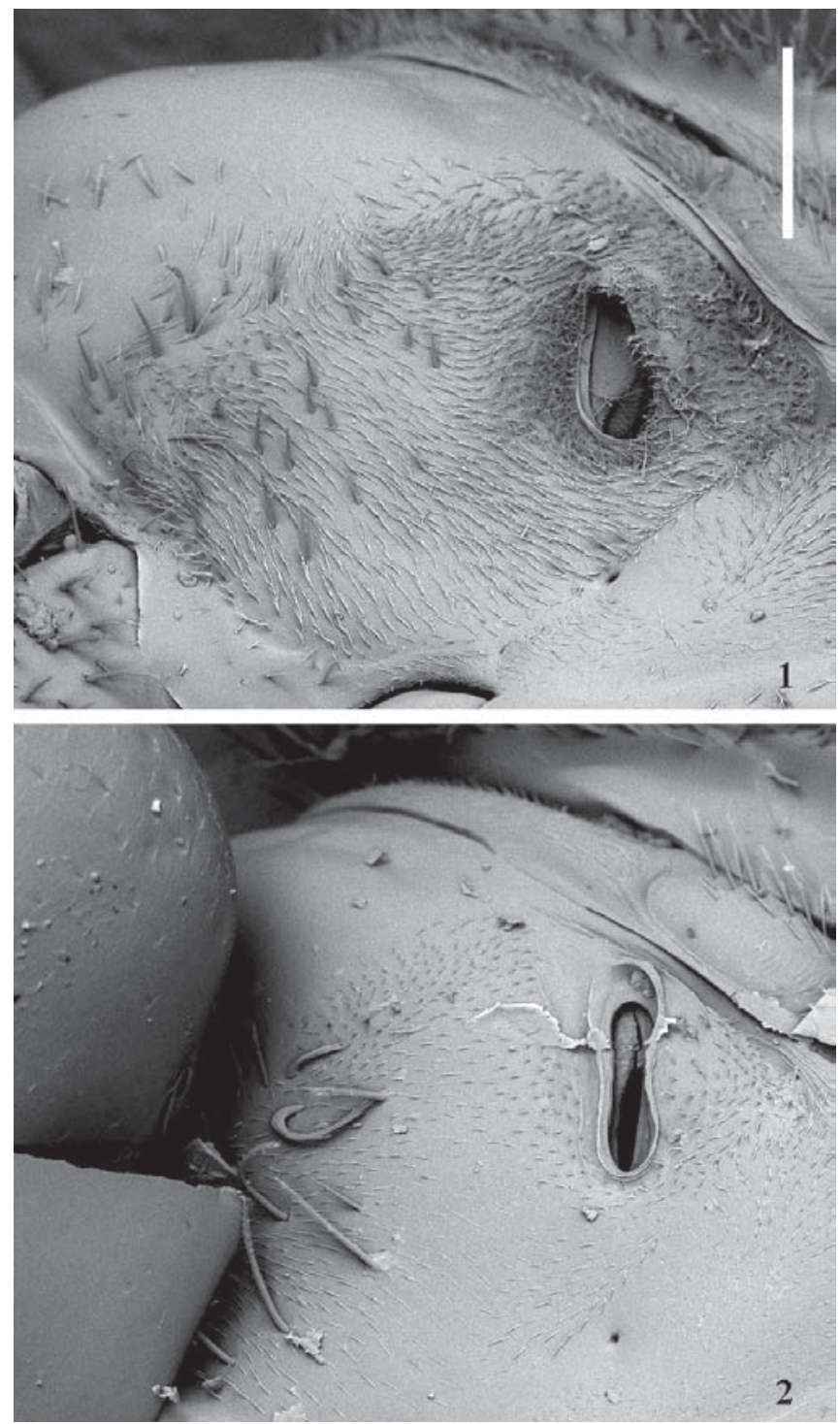

Figs. 1-2. Espiráculo propodeal, em vista látero-posterior: 1. Lestrimelitta limao (Smith); 2. Lestrimelitta rufipes (Friese). Escala $=200 \mu \mathrm{m}$.

internas convergentes inferiormente; área malar $1 / 3$ do diâmetro do escapo $(0,06: 0,18)$. Bordo posterior do escutelo com cerdas amareladas, um pouco encurvadas para cima, algumas espatuladas no ápice, de aproximadamente $0,45 \mathrm{~mm}$. Espiráculo propodeal alongado, aproximadamente 7 vezes mais longo que largo $(0,27: 0,04)$. Tíbias médias com cerdas amareladas, longas e densas $(0,44 \mathrm{~mm})$ no bordo posterior, algumas espatuladas no ápice; no ápice da face externa e do bordo anterior, cerdas mais curtas, com ramificações curtas próximo à base das cerdas; esporão mesotibial normal como o da operária. Tíbias posteriores com cerdas amareladas, densas e espatuladas no ápice, mais longas no bordo posterior $(0,50$ $\mathrm{mm}$ ), na face externa e bordo anterior, cerdas de aproximadamente $0,27 \mathrm{~mm}$. Metassoma com cerdas eretas $(0,10-$ $0,20 \mathrm{~mm}$ ) em T2 e cerdas na porção mediana a partir de T3, algumas com ramificações a partir do terço basal, esbranquiçadas no terço apical; T7 com cerdas de $0,47 \mathrm{~mm}$.
Material-tipo examinado. Parátipos: 4 operárias e 2 machos (DZUP) '268 c', 'GENÉTICA F. M. R. PRETO', 'Ig. Aliança - Rio Branco, RO [sic] Brasil - 17-VIII-1980, NA-20, 61 ${ }^{\circ} 14^{\prime} \mathrm{W}, 1^{\circ} 27^{\prime} \mathrm{N}$, Camargo, Mazucato, leg.' e 'Lestrimelitta guianensis [sic], Roubik, $1980^{\prime}$.

Material adicional examinado. GUIANA. 1 operária (AMNH), '1689', 'Yarikita, N. W. DISTRICT, B. Guiana, Feb, 1931, J. G. Myers' e 'Trigona (Lestrimelitta) limao (Smith) Det. H. F. Schwarz'. BRASIL. Roraima: 1 operária (DZUP), 'Brasil: Roraima, Rio Uraricoera, Ilha de Maracá', '21-30.xi.1987, J. A. Rafael e equipe', 'Inseticida fogging'; 1 operária (DZUP), 'Brasil: Roraima, Ilha de Maracá, 20-30.iii.1987, Luis S. Aquino, Arm. Malaise'; 2 operárias (RPSP), 'TÁBUA LASCADA - RR, 24/III/94, Silva Sílvio', 'Lestrimelitta glabrata, Camargo e Moure, 1989, Det. Camargo, 1996' e '30-0056'. Amazonas: 2 operárias (DZUP), 'Brasil: Amazonas, BR 174, ZF, 6 Km 9, Data. 06.07.86, Col. M. V. B. Garcia'; 8 operárias (DZUP), 'Lestrimelitta limão [sic]', 'Col. C. Clemento, Km. 60-15-2-77' e 'INPA-252'. Acre: 2 operárias (MPEG), 'Brasil, AC, Rio Branco, 25-X a 8-XI-91, F. Ramos/ A. Henriques/ I. Gorayeb/ N. Bittencourt' e 'Armadilha suspensa, 1,6 m, Mata T. Firme'. Mato Grosso: 9 operárias (DZUP), 'Koluene'.

Distribuição geográfica: amplamente distribuída na bacia amazônica (Fig. 32).

\section{Lestrimelitta limao (Smith, 1863) \\ (Figs. 1, 3, 7, 11, 17, 23, 29)}

Trigona limâo [sic] F. Smith, 1863: 506. Lectótipo operária, Brasil (BMNH).

Melipona limao; Ducke (1916: 13, 28a, 29, 39, 177, 179) (partim). Trigona (Lestrimelitta) limao; Friese (1903: 361); Schwarz (1938: 451) (partim).

Lestrimelitta limao; Schwarz (1948: 189-191) (partim); Lucas de Oliveira (1964: 39; 1968: 2); Roubik (1980: 264) (partim); Almeida \& Laroca (1982: 41) (partim); Camargo \& Moure (1989: 195, 196, 198, 202-204, 207, 208) (partim); Michener (1990: 117, 118; 2000: 787) (partim); Michener \& Roubik $(256,257)$ (partim); Ayala (1999: 1, 29, 32); Oliveira (2002: 197) (partim); Silveira et al. (2002: 88); Costa et al. (2003: 75, 77-80).

Comentários. A identidade desta espécie foi recentemente tratada por Marchi \& Melo (2004) a partir do exame do material tipo. Por este motivo, não são apresentadas aqui uma diagnose e descrição da operária. Apenas o macho é descrito, com base em um exemplar de Betim, Minas Gerais, coletado no mesmo ninho da operária descrita em Marchi \& Melo (2004). Além disso, é listado abaixo material adicional examinado. O macho de Ouro Preto d'Oeste é tentativamente colocado em L. limao apesar de apresentar cerdas mais longas no bordo posterior da tíbia posterior, não diferindo entretanto em outros aspectos.

\section{Macho.}

Diagnose. O macho de L. limao difere dos machos de $L$. spinosa sp. nov. e L. maracaia $\mathbf{s p . ~ n o v . ~ p e l a ~ a u s e ̂ n c i a ~ d e ~ c e r d a s ~}$ eretas na laterais dos mesepisternos, e de L. ciliata sp. nov. por não apresentar cerdas na região interocelar e no bordo anterior do mesoscuto e as laterais dos mesepisternos com cerdas eretas apenas na parte ventral. Assim como a operária, difere facilmente de L. rufipes por apresentar o espiráculo propodeal ovalado.

Dimensões. Tamanho aproximado do corpo: 6,56 mm; largura da cabeça: 1,96 mm; comprimento das asas anteriores: $3,48 \mathrm{~mm}$. 
Cor do integumento. Castanho-enegrecido; bordo posterior do clípeo amarelado; mandíbulas castanhas, enegrecidas no bordo cortante; mesoscuto, escutelo, tégulas, mesepisternos, pernas, T1 e T2 castanhos. Membrana alar um pouco enfumada, pterostigma e veias alares acastanhados.

Pilosidade. Microcerdas na face tão curtas como o diâmetro dos pontos; vértice sem cerdas eretas; algumas cerdas enegrecidas muito curtas ao longo do rebordo pré-occipital. Lobos pronotais e no bordo anterior das tégulas com cerdas eretas de aproximadamente $0,10 \mathrm{~mm}$. Mesoscuto com cerdas castanhas de até $0,12 \mathrm{~mm}$ nas laterais do bordo anterior e cerdas curtas e esparsas nos bordos laterais. Escutelo com algumas cerdas eretas curtas no disco; no bordo posterior, cerdas castanho-amareladas, em torno de $0,25 \mathrm{~mm}$, um pouco encurvadas para cima. Laterais dos mesepisternos com cerdas finas e curtíssimas na porção central e cerdas longas eretas na parte ventral. Flancos do propódeo com pilosidade fina e esbranquiçada, pêlos com ramificações curtas e compactas, mais densos próximo ao espiráculo propodeal. Tíbias médias com cerdas amareladas curtas $(0,10 \mathrm{~mm})$ nos bordos anteriores e posteriores e algumas cerdas semi-decumbentes muito curtas na face externa; fêmures posteriores com cerdas amareladas uniformes (em torno de $0,10 \mathrm{~mm}$ ) em toda face externa, mais densas no ápice. Tíbias posteriores com cerdas castanhoamareladas de aproximadamente $0,22 \mathrm{~mm}$ no bordo posterior, algumas com uma ou duas ramificações curtas na parte mediana da cerda, semi-decumbentes na face externa e um pouco mais curtas no bordo anterior. Metassoma com cerdas castanho-enegrecidas nas laterais de T1, aumentando em densidade e comprimento em direção a T7; cerdas de até 0,17 mmem T7.

Medidas e proporções. Cabeça mais larga do que longa e mais larga que o mesossoma $(1,96: 1,51: 1,67)$; órbitas internas convergentes inferiormente $(1,22: 1,10)$; olhos mais longos que sua largura máxima $(1,27: 0,60)$; largura dos olhos maior que a largura máxima das genas em vista lateral $(0,46: 0,31)$; clípeo aproximadamente 2,5 vezes mais largo que longo $(1,03: 0,38)$; $1^{\circ}$. flagelômero um pouco mais longo que o $2^{\circ}$. $(0,13: 0,14)$, iguais na largura $(0,14: 0,14)$; distância entre os ocelos laterais em torno de 2 vezes o diâmetro do ocelo médio $(0,40: 0,22)$; área malar a metade do diâmetro do escapo $(0,07: 0,13)$; escutelo um pouco mais largo que longo $(0,55: 0,53)$; basitarsos médios aproximadamente 7,5 vezes mais longos que sua largura máxima $(0,84: 0,11)$; basitarsos posteriores aproximadamente 4 vezes mais longos que sua largura máxima $(0,79: 0,18)$ e 1,5 vezes mais largos que os médios $(0,18: 0,11)$; tíbias posteriores aproximadamente 2,5 vezes mais longas que sua largura máxima $(1,37: 0,53)$; contorno da abertura do espiráculo propodeal ovalado, aproximadamente 2 vezes mais longo do que largo $(0,21: 0,11)$; esporão mesotibial reduzido $(0,05)$, porém visível e enegrecido.

Material adicional examinado. BRASIL. Minas Gerais: 2 operárias (RPSP), 'Conc. das Alagoas - Mg, SE 22,4820 a, 23.iii.1973, G. Penha leg'; 2 operárias e 3 machos (DZUP), 'Brasil, Minas Gerais, Divinópolis, I. Stanciola leg., colônia 453M-UFV, 4.I.1995'; 23 operárias (DZUP), 'Brasil, Minas Gerais, $25 \mathrm{~km}$ a NO de Janaúba, 21.I.2005, $15^{\circ} 40^{\prime} \mathrm{S}, 43^{\circ} 31^{\prime} \mathrm{W}, 520 \mathrm{~m}$, Melo \& Costa'; 5 operárias
(UFMG), 'Venda Nova, 8277-24986' e 'Belo Horizonte, MG, BRASIL/ $11 / 2002$, B. A. Ribeiro'; 8 operárias (UFMG), 'Faz. Jacaré, 835525513'e 'Felixlândia, MG, BRASIL, 17/02/2003, A. A. Azevedo'. São Paulo: 1 operária (MPEG), 'Franca, E. ${ }^{\text {s }}$ de S. Paulo'; 1 operária (UFMG), 'UNESP, Bauru, SP, Brasil, 8,12,1997, Col.: F. KNOLL PI SAL. MET. C. U.' Rondônia: 1 macho (MPEG), 'Brasil, Rondônia, Ouro Preto de Oeste, 3 a 5.IX.1986', 'Brasil, Rondônia, F. F. Ramos' e 'Armadilha Suspensa $15 \mathrm{~m}$ '.

Distribuição geográfica: restrita a áreas de cerrado, do Maranhão a São Paulo, conforme as localidades aqui listadas e dados da literatura (Fig. 29).

\section{Lestrimelitta monodonta Camargo \& Moure, 1989}

(Fig. 30)

Lestrimelitta monodonta Camargo \& Moure, 1989: 196. Holótipo operária, Brasil: Roraima, Ilha de Maracá (RPSP; não examinado); Camargo \& Moure (1989: 203, 205, 209-211); Oliveira (2002: 197); Silveira et al. (2002: 88).

Diagnose e Comentários. Apresenta somente um dente no bordo interno das mandíbulas, ao contrário de dois dentes pequenos das demais espécies, assim como a cabeça e o mesoscuto revestidos com pilosidade decumbente longa e densa (principalmente as genas) e as laterais dos mesepisternos cerdosas (as cerdas na porção anterior distintamente mais longas). Camargo \& Moure (1989) apresentam figuras da cabeça, dentes das mandíbulas e do mesossoma da operária.

Os espécimes coletados em Tucuruí (PA), Jacareacanga (PA) e Urbano Santos (MA) têm tamanho corporal menor, quando comparados aos outros da mesma espécie, porém não foram observados outros caracteres que poderiam indicar tratar-se de espécies distintas.

Operária. Comprimento total aproximado: $6,08 \mathrm{~mm}$; comprimento das asas anteriores: $4,12 \mathrm{~mm}$; largura da cabeça: $2,16 \mathrm{~mm}$. Integumento predominantemente castanhoenegrecido; mandíbulas e porção central do clípeo, castanhos. Apenas um dente no bordo interno das mandíbulas. Órbitas internas convergentes inferiormente. Comprimento da área malar praticamente a metade do diâmetro do escapo. Cabeça com pilosidade longa, decumbente e densa; cerdas conspícuas somente no ápice dos escapos; cerdas eretas curtas no vértice e cerdas castanhas semi-eretas relativamente longas no rebordo pré-occipital. Lobos pronotais com cerdas eretas castanhas (em torno de $0,10 \mathrm{~mm}$ ) e com pilosidade plumosa curta no seu limite com os mesepisternos; bordo anterior das tégulas com cerdas eretas castanho-amareladas (com cerca de 0,10 mm). Mesoscuto com as cerdas do bordo anterior concentradas na porção mediana e nas laterais, com aproximadamente $0,10 \mathrm{~mm}$; cerdas mais curtas nos bordos laterais e axilas; no disco, pêlos decumbentes relativamente longos. Escutelo com cerdas esbranquiçadas, densas e encurvadas para cima; no bordo posterior, em torno de $0,30 \mathrm{~mm}$; eretas e um pouco mais curtas no disco. Laterais dos mesepisternos com cerdas eretas castanhas $(0,08 \mathrm{~mm})$, as mais longas $(0,16 \mathrm{~mm})$ na porção 

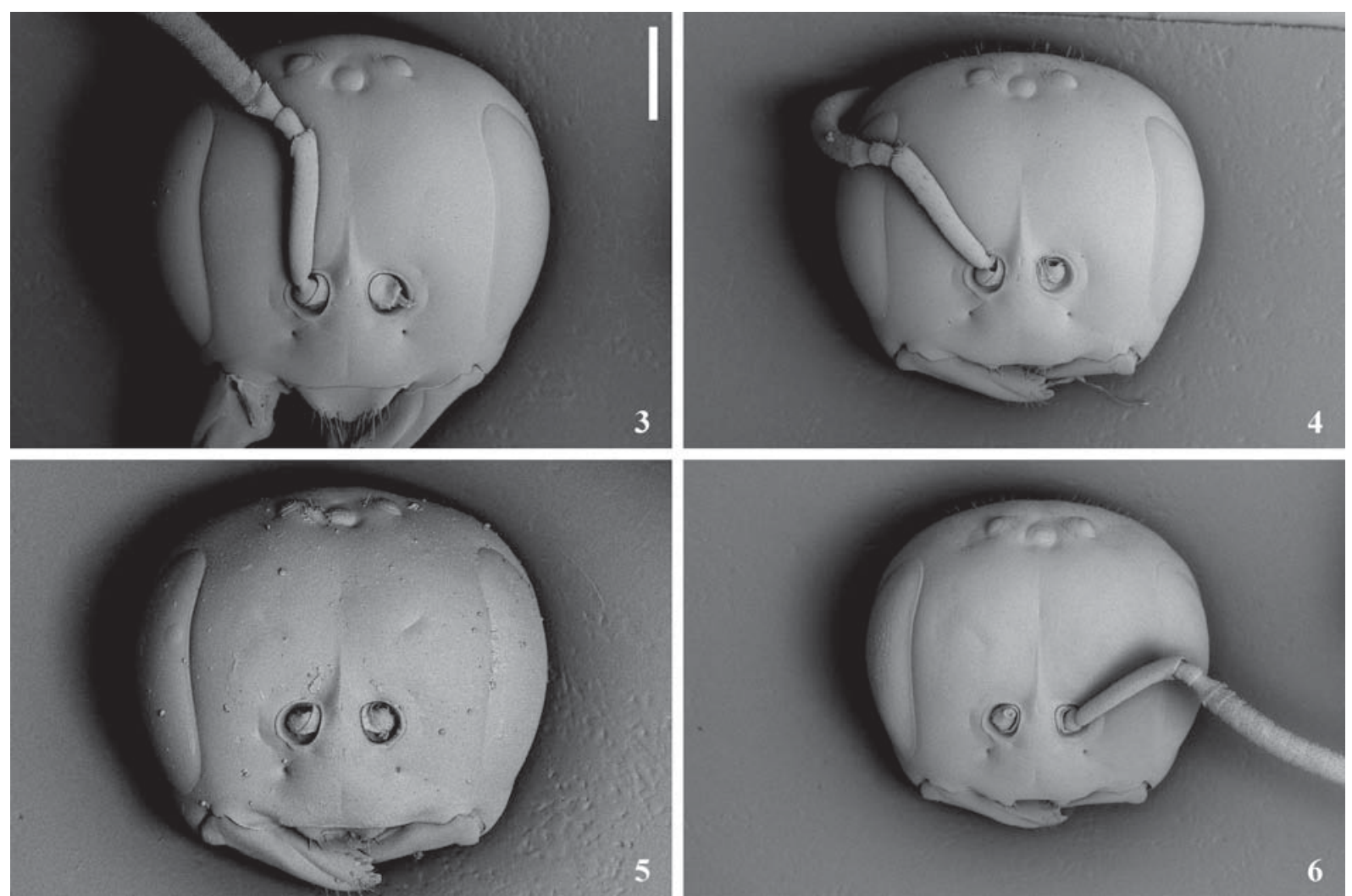

Figs. 3-6. Cabeça, vista frontal: 3. Lestrimelitta limao (Smith); 4. Lestrimelitta rufipes (Friese); 5. Lestrimelitta spinosa sp. nov.; 6. Lestrimelitta tropica sp. nov. Escala $=500 \mu \mathrm{m}$.

anterior, abaixo do lobo pronotal. Pilosidade ramificada nos flancos do propódeo, os pêlos mais longos e ramificados próximo ao espiráculo propodeal; espiráculo propodeal alongado, 4 vezes mais longo do que largo $(0,19: 0,05)$. Tíbias médias com as cerdas do bordo posterior duas vezes mais longas que as do bordo anterior; esporão mesotibial reduzido. Fêmures posteriores com cerdas castanho-enegrecidas uniformes em toda a face externa. Tíbias posteriores com cerdas de aproximadamente $0,20 \mathrm{~mm}$ no bordo posterior e cerdas com metade deste comprimento no bordo anterior. Cerdas acastanhadas nas laterais de $\mathrm{T} 1 \mathrm{e}$ laterais e bordo posterior de T2; T3 a T6 cerdosos.

Macho. Desconhecido.

Material examinado. BRASIL. Roraima: 61 operárias (DZUP), 'Ilha de Maracá - RR 23-28/II/1988, Mielke \& Mirna col.'; 10 operárias (DZUP), 'Ilha de Maracá, Alto Alegre - RR 20-26/VI/1988, Mielke e Mirna'; 6 operárias (INPA), 'BRASIL, Roraima, Rio Uraricoera, Ilha de Maracá' e '21-XI-1987, L. S. Aquino'; 12 operárias (INPA), idem, exceto '24.iv.1987, F. J. A Peralta' e '37'; 1 operária (INPA), idem, exceto '26.iv.1987, F. J. A Peralta' e '37'; 5 operárias (INPA), 'Brasil: Roraima, Ilha de Maracá, 25-V-1988, F. J. A. Peralta'. Amazonas: 12 operárias (INPA), 'RPSP 831 c', 'Ponta do Gavião, rio Negro AM, Brasil, 29-31.VII.1999, 62 ${ }^{\circ} 12^{\prime}$ W. 01 ${ }^{\circ} 18^{\prime}$ 'S, Camargo, Pedro, Mazucato' e 'Lestrimelitta monodonta Camargo \& Moure, 1988 Det. Camargo, 2000'. Pará: 1 operária (MPEG), 'Brasil, Pará, Tucuruí, Rio Tocantins, CHIQUEIRÃO, 07-vi-84; 1 operária (DZUP), ' JACAREACANGA, Pará Brasil, x-1959, M. Alvarenga leg.'; 1 operária (MPEG), 'BrasilPará, 2 a 6-XII-1983, col. I. S. Gorayeb', 'APEG, Armadilha Suspensa 1,6 m' e 'Lestrimelitta monodonta, det. G. A. R. Melo, 2004'; 1 operária, idem, exceto 'APEG, Armadilha Suspensa 23 m'. Maranhão: 1 operária (DZUP), 'BR - MA - Urbano Santos - Faz. Bonfim, 24/III/2003, Serra, B.D.V. leg. N 033’.

Distribuição geográfica: com ampla distribuição, indo de Roraima, ao norte, até os cerrados do Maranhão, a leste (Fig. 30).

\section{Lestrimelitta nana Melo, 2003}

(Fig. 32)

Lestrimelitta nana Melo, 2003: 85. Holótipo operária, Brasil: Amapá, bacia do rio Cajari, Santa Rosa (DZUP).

Diagnose e Comentários. É a menor espécie conhecida deste gênero, sendo as operárias praticamente glabras. Além do tamanho reduzido, separa-se de L. glaberrima pelas órbitas internas convergentes inferiormente e o esporão mesotibial normal, de L. glabrata e L. guyanensis pela ausência de cerdas longas no bordo posterior das tíbias médias, por apresentar algumas cerdas nos lobos pronotais e o metassoma com cerdas apenas nos tergos apicais. Apesar de ter a abertura do espiráculo propodeal ovalada, não parece ser estreitamente relacionada a $L$. limao e espécies próximas, em que o espiráculo, além de ter a abertura ovalada, apresenta a parte superior projetada, em comparação com a parte inferior (vide Figs. 23, 24, 26-28). 
Operária. Comprimento total aproximado: $4,21 \mathrm{~mm}$; comprimento das asas anteriores: $3,20 \mathrm{~mm}$; largura da cabeça: $1,56 \mathrm{~mm}$. Abelhas muito pequenas; órbitas internas convergentes inferiormente; área malar um pouco menor que o diâmetro do escapo $(0,08: 0,11)$. Integumento castanhoenegrecido e praticamente glabro. Vértice com poucas cerdas muito curtas; cerdas conspícuas somente no ápice dos escapos. Mesoscuto e laterais dos mesepisternos sem cerdas eretas. Bordo anterior dos lobos pronotais com poucas cerdas eretas castanho-enegrecidas muito curtas, algumas com até $0,08 \mathrm{~mm}$. Bordo posterior do escutelo com algumas cerdas eretas enegrecidas, relativamente curtas, em torno de $0,17 \mathrm{~mm}$. Tíbias médias com algumas cerdas castanhas próximo ao ápice dos bordos anterior e posterior; esporão mesotibial normal. Fêmures posteriores com algumas cerdas enegrecidas e espessas apenas próximo ao ápice da face externa. Tíbias posteriores com cerdas castanho-enegrecidas, as mais longas com $0,12 \mathrm{~mm}$ no bordo posterior e um pouco mais curtas $(0,10$ $\mathrm{mm}$ ) e decumbentes no bordo anterior. Flancos do propódeo com pilosidade curta, fina e esparsa; espiráculo propodeal ovalado, 3 vezes mais longo do que sua largura máxima $(0,15: 0,05)$. Metassoma com microcerdas nas laterais de $\mathrm{T} 1 \mathrm{e}$ nas laterais e bordos posteriores de T2, T3 e T4; cerdas enegrecidas, espessas e mais longas nas laterais e bordo posterior de T5; T6 com cerdas de até $0,18 \mathrm{~mm}$.

Macho. Desconhecido.

Material-tipo examinado. BRASIL. Amapá: holótipo operária (DZUP), 'Brasil, Amapá, Rio Cajari, Santa Rosa, 0³5'46'”S, 52 ${ }^{\circ} 19^{\prime} 30^{\prime \prime}$ W, 18.ix.2001 G. A. R. Melo \& O. Silveira', 'Atacando ninho de Leurotrigona em esteio de cabana', 'HOLOTIPO, Lestrimelitta nana Melo, 2003'. Parátipos: 4 operárias (DZUP), mesmos dados do holótipo.

Distribuição geográfica: Espécie registrada apenas para o Estado do Amapá (Fig. 32).

\section{Lestrimelitta rufa (Friese, 1903)}

(Figs. 12, 18, 24, 30)

Trigona (Lestrimelitta) limao var. rufa Friese, 1903: 361. Lectótipo operária, aqui designado, Brasil: Acre, rio Acre (AMNH). Schwarz (1948: 182).

Melipona limao var. rufa; Ducke (1916: 40, 178).

Lestrimelitta limao var. rufa; Friese (1930: 11).

Lestrimelitta limao; Schwarz (1948: 185 [Fig. 4, rainha], 191 [espécimes do Acre]).

Diagnose e Comentários. Esta espécie distingue-se de $L$. sulina $\mathbf{s p . ~ n o v . ~ e ~ L . ~ t r o p i c a ~} \mathbf{s p . ~ n o v . ~ p o r ~ a p r e s e n t a r ~ a s ~ o ́ r b i t a s ~}$ internas paralelas e pilosidade tomentosa, cobrindo totalmente o integumento nos flancos do propódeo. As cerdas do disco do mesoscuto e do escutelo são mais curtas e esparsas em relação a $L$. sulina $\mathbf{~ s p . ~ n o v . ~ e ~ n a ̃ o ~ s a ̃ o ~ e s b r a n q u i c ̧ a d a s ~ n o ~ a ́ p i c e . ~}$ Os mesepisternos são totalmente cerdosos, enquanto $L$. sulina sp. nov. tem cerdas nos dois terços inferiores e L. tropica $\mathbf{s p .}$ nov., apenas na parte ventral. O macho desta espécie difere de L. sulina sp. nov. e de L. tropica $\mathbf{s p . ~ n o v . ~ p e l a ~ p i l o s i d a d e ~}$ tomentosa nos flancos do propódeo e cerdas a partir das laterais de T2. Lestrimelitta rufa apresenta esporão mesotibial reduzido, exceto pelo lectótipo e um espécime de Ouro Preto d'Oeste com esporão curto em uma das pernas.

O exemplar pertencente ao $\mathrm{AMNH}$, marcado com o número 370, como indicado por Friese (1903), é aqui designado lectótipo para estabilizar a taxonomia do grupo. Trata-se de um teneral coletado diretamente no ninho por Ducke, no rio Acre, ainda sem a pigmentação característica de indivíduos maduros. Abaixo é apresentada a redescrição da operária baseada no lectótipo; o macho aqui descrito é de Cáceres, Mato Grosso. Uma diagnose para a cor do integumento, baseada em uma operária de Ouro Preto D'Oeste, Rondônia, é como segue: predominantemente enegrecido; flagelos e extremidades da parte ventral dos escapos castanhos; mandíbulas castanhoavermelhadas, enegrecidas na base e ápice; coxas, trocanteres e tarsos castanhos; extremidades distais das tíbias posteriores e laterais de T1 castanho-avermelhadas. Membrana alar um pouco enfumada, pterostigma e veias alares castanhos.

\section{Operária.}

Dimensões. Comprimento total aproximado: 7,05 mm; comprimento das asas anteriores: $4,41 \mathrm{~mm}$; largura da cabeça: $2,30 \mathrm{~mm}$.

Cor do integumento. Espécime teneral, sem a pigmentação característica de indivíduos maduros.

Pilosidade. Microcerdas na face tão curtas como o diâmetro dos pontos, um pouco mais longas (2DP) nas genas, mais densas na fronte, clípeo e genas; algumas cerdas eretas de $0,05 \mathrm{~mm}$ no ápice escapos. Cerdas eretas no vértice (de aproximadamente $0,08 \mathrm{~mm}$ ) e ao longo do rebordo pré-occipital. Lobos pronotais e bordo anterior das tégulas com cerdas eretas mais longas, de $0,13-0,15 \mathrm{~mm}$. Mesoscuto com cerdas longas $(0,20 \mathrm{~mm})$ no bordo anterior, algumas com poucas ramificações (compactas); nos bordos laterais e no disco, cerdas mais curtas (em torno de 0,07 mm). Escutelo com cerdas eretas finas, longas (aproximadamente $0,25 \mathrm{~mm}$ ), encurvadas para cima no bordo posterior e cerdas mais curtas e eretas no disco. Laterais dos mesepisternos com cerdas de aproximadamente $0,08 \mathrm{~mm}$. Flancos do propódeo com pilosidade muito ramificada e densa, formando tomento. Tíbias médias com pilosidade decumbente na face externa um pouco mais longa que nas tíbias anteriores, cerdas uniformemente castanhas no bordo posterior e um pouco mais curtas no bordo anterior. Fêmures posteriores com cerdas enegrecidas mais curtas e esparsas na porção central da face externa. Tíbias posteriores com cerdas em torno de $0,18 \mathrm{~mm}$ no bordo anterior, e um pouco mais longas no bordo posterior. Metassoma com cerdas a partir das laterais de T2, aumentando em densidade e comprimento em direção a T6; T3 e T4 com microcerdas no bordo posterior; T5 e T6 cerdosos.

Medidas e proporções. Cabeça mais larga do que longa e mais larga que o mesossoma $(2,30: 1,86: 1,71)$; órbitas internas paralelas $(1,42)$; olhos mais longos que sua largura máxima $(1,42: 0,64)$; largura dos olhos em perfil menor que a das genas $(0,54: 0,64)$; clípeo quase 3 vezes mais largo que longo $(1,08: 0,38) ; 1^{\circ}$. flagelômero 2 vezes mais longo que o $2^{\circ}$. $(0,16: 0,08)$, e praticamente iguais na largura $(0,16: 0,17)$; distância 
entre os ocelos laterais 2 vezes o diâmetro do ocelo médio $(0,34: 0,17)$; área malar um pouco menor que o diâmetro do escapo $(0,11: 0,13)$; escutelo mais largo que longo $(0,63: 0,54)$; basitarsos médios 5 vezes mais longos que sua largura máxima $(0,82: 0,16)$; basitarsos posteriores aproximadamente 2,5 vezes mais longos que sua largura máxima $(0,81: 0,34)$ e 2 vezes mais largos que os médios $(0,34: 0,16)$; tíbias posteriores em torno de 3 vezes mais longas que sua largura máxima $(1,59: 0,54)$; espiráculo propodeal ovalado, cerca de 2 vezes mais longo do que largo $(0,15: 0,09)$; esporão mesotibial reduzido $(0,06$ na perna direita e 0,11 na esquerda).

\section{Macho.}

Dimensões. Tamanho aproximado do corpo: 7,35 mm; largura da cabeça: $2,11 \mathrm{~mm}$ e comprimento das asas anteriores: $4,31 \mathrm{~mm}$.

Cor do integumento. Castanho-enegrecido; mandíbulas castanhas, enegrecidas na base e ápice; clípeo com mancha amarelada no bordo posterior, base dos escapos, lobos pronotais, pernas e os três primeiros tergos abdominais castanhos.

Pilosidade. Microcerdas na face tão curtas como o diâmetro dos pontos, um pouco mais longas (2DP) na fronte e genas. Escapos com cerdas eretas conspícuas apenas no ápice. Vértice com cerdas eretas enegrecidas (com cerca de $0,11 \mathrm{~mm}$ ) e cerdas um pouco mais curtas ao longo do rebordo préoccipital. Mesoscuto com cerdas castanho-enegrecidas (de aproximadamente $0,16 \mathrm{~mm}$ ) nas laterais e na porção mediana do bordo anterior; cerdas um pouco mais curtas nos bordos laterais; no disco, algumas cerdas curtas $(0,06 \mathrm{~mm})$. Escutelo com cerdas eretas castanhas no disco (em torno de $0,11 \mathrm{~mm}$ ); no bordo posterior, cerdas castanhas, enegrecidas no ápice e um pouco encurvadas para cima, medindo até $0,30 \mathrm{~mm}$. Lobos pronotais com cerdas eretas castanhas $(0,11 \mathrm{~mm})$ e pilosidade plumosa curta e amarelada no limite com os mesepisternos. Tégulas com cerdas castanho-amareladas de $0,06 \mathrm{~mm}$, algumas mais longas no bordo anterior. Laterais dos mesepisternos com cerdas eretas castanho-amareladas (com cerca de 0,07 $\mathrm{mm}$ ). Flancos do propódeo com pilosidade muito ramificada e densa (tomentosa). Face externa das tíbias médias com pilosidade decumbente mais longa que nas tíbias anteriores e com algumas cerdas semi-decumbentes muito curtas; nos bordos anteriores e posteriores, cerdas castanho-amareladas, um pouco mais longas próximas ao ápice. Fêmures posteriores com cerdas enegrecidas mais curtas e esparsas na porção central da face externa. Tíbias posteriores com cerdas amareladas de até $0,35 \mathrm{~mm}$, algumas com ramificações curtas na metade apical no bordo posterior; semi-decumbentes e longas na face dorsal e mais curtas e encurvadas no bordo anterior. Metassoma com cerdas castanho-enegrecidas a partir das laterais de T2, aumentando em comprimento e densidade em direção ao último tergo, algumas cerdas curtas no bordo posterior de T4, T5 e T6; T7 com cerdas de aproximadamente $0,30 \mathrm{~mm}$.

Medidas e proporções. Cabeça mais larga do que longa e mais larga que o mesossoma $(2,11: 1,56: 1,86)$; órbitas internas convergentes inferiormente $(1,27: 1,17)$; olhos mais longos que sua largura máxima $(1,17: 0,62)$; largura dos olhos, em perfil, 2 vezes maior que a largura máxima das genas $(0,62: 0,29)$; clípeo aproximadamente 3 vezes mais largo que longo $(1,10: 0,43) ; 1^{\circ}$. e $2^{\circ}$. flagelômeros iguais no comprimento $(0,18: 0,18)$ e na largura $(0,16: 0,16)$; distância entre os ocelos laterais um pouco menor que 2 vezes o diâmetro do ocelo médio $(0,36: 0,20)$; área malar aproximadamente metade do diâmetro do escapo $(0,09: 0,16)$; escutelo mais largo que longo $(0,71: 0,59)$; basitarsos médios 7 vezes mais longos que sua largura máxima $(0,87: 0,12)$; basitarsos posteriores aproximadamente 4 vezes mais longos que sua largura máxima $(0,84: 0,19)$ e um pouco mais largos que os médios $(0,19: 0,12)$; tíbias posteriores 3 vezes mais longas que sua largura máxima $(1,51: 0,53)$; contorno da abertura do espiráculo propodeal ovalado, aproximadamente 2 vezes mais longo do que largo $(0,14: 0,07)$; esporão mesotibial reduzido $(0,03)$.

Material-tipo. Lectótipo operária (AMNH), aqui designado, com as seguintes etiquetas: 'Brasil, Pará, 370, 1900, Ducke, Rio Acre' e 'acc 35178'. Na etiqueta, o número '370' e 'Rio Acre' estão escritos a lápis. A seguinte etiqueta foi adicionada: 'Lectotype, Trigona (Lestrimelitta) limao v. rufa Friese, 1903, des. Marchi \& Melo, 2004'. Paralectótipos: 3 operárias (MPEG), 'Rio Acre, 1902' (manuscrita do Ducke) e 'Brazil, Estado do Amazonas' (material em péssimo estado, 2 operárias sem cabeça); 1 rainha (AMNH), 'Rio Acre, 1902' e 'Lestrimelitta limao Sm., Friese det. 25, nesttier'. Os paralectótipos também receberam etiquetas correspondentes. Não foram encontrados espécimes no ZMHB, em Berlim (F. Koch, comunicação pessoal).

Material adicional examinado: BRASIL. Pará: 1 macho (MPEG), 'Brasil, Pará, Serra Norte, Est. N. Serraria, 7 a 10.IX.1983, Col. F. F. Ramos, Arm. Malaise'; 1 macho (MPEG), 'Brasil, Pará, Melgaço, Caxiuanã, ECFPn, 01.V.1999, O. Silveira \& J. Dias' e ‘ Percurso 3, Arm. S. malaise, Caxiuanã'. Rondônia: 15 operárias (DZUP), 'Ouro Preto d'Oeste, RO, 13-XI 1987, C. Elias, leg' e 'Projeto Polonoroeste'; 2 operárias (SEMK), idem; 4 operárias, idem, exceto '18-X-1987'; 6 operárias, idem, exceto '29-X-1987'; 1 operária, idem, exceto '22-IX-1987'; 1 operária (RPSP), 'Brasil. Rondônia, GuajaráMirim, As. Pacaás Novos', 'PN 0266' e '16/junho/1995, M. L. Oliveira'. Mato Grosso: 1 macho (DZUP), 'Caceres, MT, 27/III/1985, C. Elias leg. POLONOROESTE'. EQUADOR. 1 operária (AMNH), 'Tena, Ecuador, March 4. 1923', 'F. Williams Collector', 'Trigona (Lestrimelitta) limao (Smith), Det. H. F. Schwarz' e 'acc 35873'.

Distribuição geográfica. No Brasil, encontrada no sul e oeste da bacia amazônica, chegando até o Equador, a oeste (Fig. 30).

\section{Lestrimelitta rufipes (Friese, 1903)}

(Figs. 2, 4, 8, 13, 19, 25, 31)

Trigona (Lestrimelitta) limao var. rufipes Friese, 1903: 361. Lectótipo operária, aqui designado, Brasil: São Paulo, Bauru (AMNH). Schwarz (1948: 182).

Melipona limao var. rufipes; Ducke (1916: 40, 178)

Lestrimelitta limao; Schwarz (1948: 187 [Fig. 5, macho], 191 [espécimes de Bauru, São Paulo]).

Diagnose e Comentários. Esta espécie separa-se facilmente de L. limao, L. rufa e das seguintes espécies novas: L. sulina sp. nov., L. tropica sp. nov. , L. spinosa $\mathbf{s p . ~ n o v . , ~ L . ~ m a r a c a i a ~ s p . ~}$ nov. e L. ciliata sp. nov. pelo formato alongado do espiráculo 
propodeal e ausência de cerdas eretas longas nos lobos pronotais e no bordo anterior das tégulas. Difere de $L$. similis sp. nov. por apresentar o mesoscuto com cerdas eretas em todo bordo anterior e na porção mediana do terço anterior do disco e o metassoma com cerdas a partir das laterais de T2. Macho sem cerdas eretas no vértice e bordo anterior do mesoscuto com poucas cerdas muito curtas. Difere do macho de L. glaberrima pelos seguintes caracteres: escutelo com cerdas eretas longas nos dois terços posteriores; face externa das tíbias posteriores cerdosa e metassoma com cerdas eretas a partir das laterais de T3.

Há pequenas variações entre os exemplares de diferentes localidades, como a pontuação da face e as cerdas do metassoma. Uma análise mais aprofundada poderá revelar, eventualmente, tratar-se de um complexo de espécies. A redescrição foi baseada no lectótipo, operária, e um paralectótipo, macho, de Bauru, São Paulo.

\section{Operária.}

Dimensões. Comprimento total aproximado: $7,25 \mathrm{~mm}$; comprimento das asas anteriores: $4,41 \mathrm{~mm}$; largura da cabeça: 2,28 mm.

Cor do integumento. Predominantemente castanho; face ventral das antenas castanho-clara; mandíbulas castanhoavermelhadas, enegrecidas no bordo anterior; pernas castanho-avermelhadas. Membrana alar muito pouco enfumada, pterostigma e veias alares castanho-claros.

Pilosidade. Microcerdas na face tão curtas como o diâmetro dos pontos. Vértice com cerdas eretas castanhas (em torno de $0,18 \mathrm{~mm}$ ), um pouco mais curtas no rebordo pré-occipital. Escapos com cerdas eretas conspícuas apenas no ápice. Lobos pronotais e tégulas sem cerdas eretas. Bordo anterior do mesoscuto com muitas cerdas eretas acastanhadas (de 0,15 $\mathrm{mm}$ ), mais densas nas laterais e na porção mediana, algumas com ramificações curtas e compactas próximas ao ápice; no disco, algumas cerdas eretas esparsas, mais longas e densas na porção mediana do terço anterior; nos bordos laterais, cerdas eretas um pouco mais curtas e esparsas (em torno de $0,10 \mathrm{~mm}$ ) anteriormente e mais longas $(0,20 \mathrm{~mm})$ próximo às axilas. Escutelo com cerdas eretas no disco (em torno de 0,15 $\mathrm{mm}$ ); no bordo posterior, uniformemente castanhas, algumas encurvadas para cima, com até $0,35 \mathrm{~mm}$. Laterais dos mesepisternos com microcerdas esparsas; cerdas eretas longas restritas à porção ventral. Flancos do propódeo com pilosidade densa, porém curtíssima e fina. Tíbias médias com pilosidade decumbente fina mais longa que nas tíbias anteriores, sem cerdas na face externa; nos bordos anterior e posterior, cerdas castanho-amareladas curtas. Fêmures posteriores com cerdas não uniformemente distribuídas na face externa, mais longas e densas próximas ao ápice e mais curtas e esparsas na porção central. Tíbias posteriores com as cerdas do bordo posterior castanhas (de até $0,40 \mathrm{~mm}$ ); no bordo anterior, cerdas um pouco mais curtas. Metassoma com cerdas enegrecidas a partir das laterais de T2 $(0,12 \mathrm{~mm})$, tornando-se gradativamente mais longas nos demais tergos. Bordo posterior de T1 glabro; de T2 e T3, com pouquíssimas cerdas muito curtas, esparsas lateralmente e ausentes na porção mediana; $\mathrm{T} 4$ com cerdas um pouco mais longas e densas; T5 e T6 com cerdas castanhoescuras, as mais longas com cerca de $0,25 \mathrm{~mm}$ em T6.

Medidas e proporções. Cabeça mais larga do que longa e mais larga que o mesossoma (2,28: 1,76:1,61:); órbitas internas paralelas $(1,57: 1,57)$; olhos em torno de 2 vezes mais longos que sua largura máxima $(1,27: 0,59)$; largura dos olhos menor que a largura das genas em vista lateral $(0,49: 0,59)$; clípeo aproximadamente 3 vezes mais largo que longo $(1,13: 0,44) ; 1^{\circ}$. flagelômero 2 vezes mais longo que o $2^{\circ}$. $(0,17: 0,08)$, iguais na largura $(0,16: 0,16)$; distância entre os ocelos laterais aproximadamente 2 vezes o diâmetro do ocelo médio $(0,38: 0,16)$; área malar um pouco menor que o diâmetro do escapo $(0,14: 0,15)$; escutelo tão largo quanto longo $(0,78: 0,83)$; basitarsos médios aproximadamente 4 vezes mais longos que sua largura máxima $(0,69: 0,20)$; basitarsos posteriores aproximadamente 3 vezes mais longos que sua largura máxima $(0,93: 0,37)$ e em torno de 2 vezes mais largos que os médios $(0,37: 0,20)$; tíbias posteriores 3 vezes mais longas que sua largura máxima $(1,62: 0,54)$; contorno da abertura do espiráculo propodeal alongado, 5 vezes mais longo do que largo $(0,26: 0,05)$; esporão mesotibial curto (aproximadamente 0,18$)$.

\section{Macho.}

Dimensões. Tamanho aproximado do corpo: $6,56 \mathrm{~mm}$; largura da cabeça: 2,10 $\mathrm{mm}$; comprimento das asas anteriores: $4,06 \mathrm{~mm}$.

Cor do integumento. Predominantemente castanho; bordo posterior do clípeo, parte ventral dos escapos, fronte, áreas paroculares inferiores e pernas castanho-amarelados; mandíbulas castanhas, enegrecidas no bordo cortante; mesoscuto, escutelo, tégulas, mesepisternos, pernas, T1 e T2 castanho-claros. Membrana alar semelhante à da operária.

Pilosidade. Microcerdas da face tão curtas como o diâmetro dos pontos. Vértice, rebordo pré-occipital, lobos pronotais e tégulas sem cerdas eretas. Bordo anterior do mesoscuto com poucas cerdas muito curtas $(0,08 \mathrm{~mm})$. Escutelo com cerdas castanho-amareladas, em torno de $0,35 \mathrm{~mm}$, nos dois terços posteriores. Mesepisternos com cerdas eretas apenas na parte ventral. Flancos do propódeo com pilosidade densa, bastante curta e fina. Tíbias médias com cerdas amareladas (em torno de $0,20 \mathrm{~mm}$ ) relativamente esparsas apenas nos bordos anteriores e posteriores. Fêmures posteriores com cerdas enegrecidas mais longas apenas no ápice. Tíbias posteriores com cerdas amareladas longas (em torno de $0,50 \mathrm{~mm}$ ) no bordo posterior, algumas conspicuamente ramificadas; cerdas semidecumbentes na face externa e um pouco mais curtas no bordo anterior. Metassoma com algumas cerdas curtíssimas $(0,05 \mathrm{~mm})$ nas laterais de T2; cerdas castanhas mais longas $(0,20 \mathrm{~mm})$ nas laterais de T3 e T4; 0,35 mm nas laterais de T5 e T6; T7 com cerdas de até $0,17 \mathrm{~mm}$.

Medidas e proporções. Cabeça mais larga do que longa e mais larga que o mesossoma $(2,10: 1,62: 1,62)$; órbitas internas convergentes inferiormente $(1,32: 1,13)$; olhos mais longos que sua largura máxima $(1,27: 0,60)$; largura dos olhos maior que a largura máxima das genas em vista lateral $(0,46: 0,31)$; clípeo 

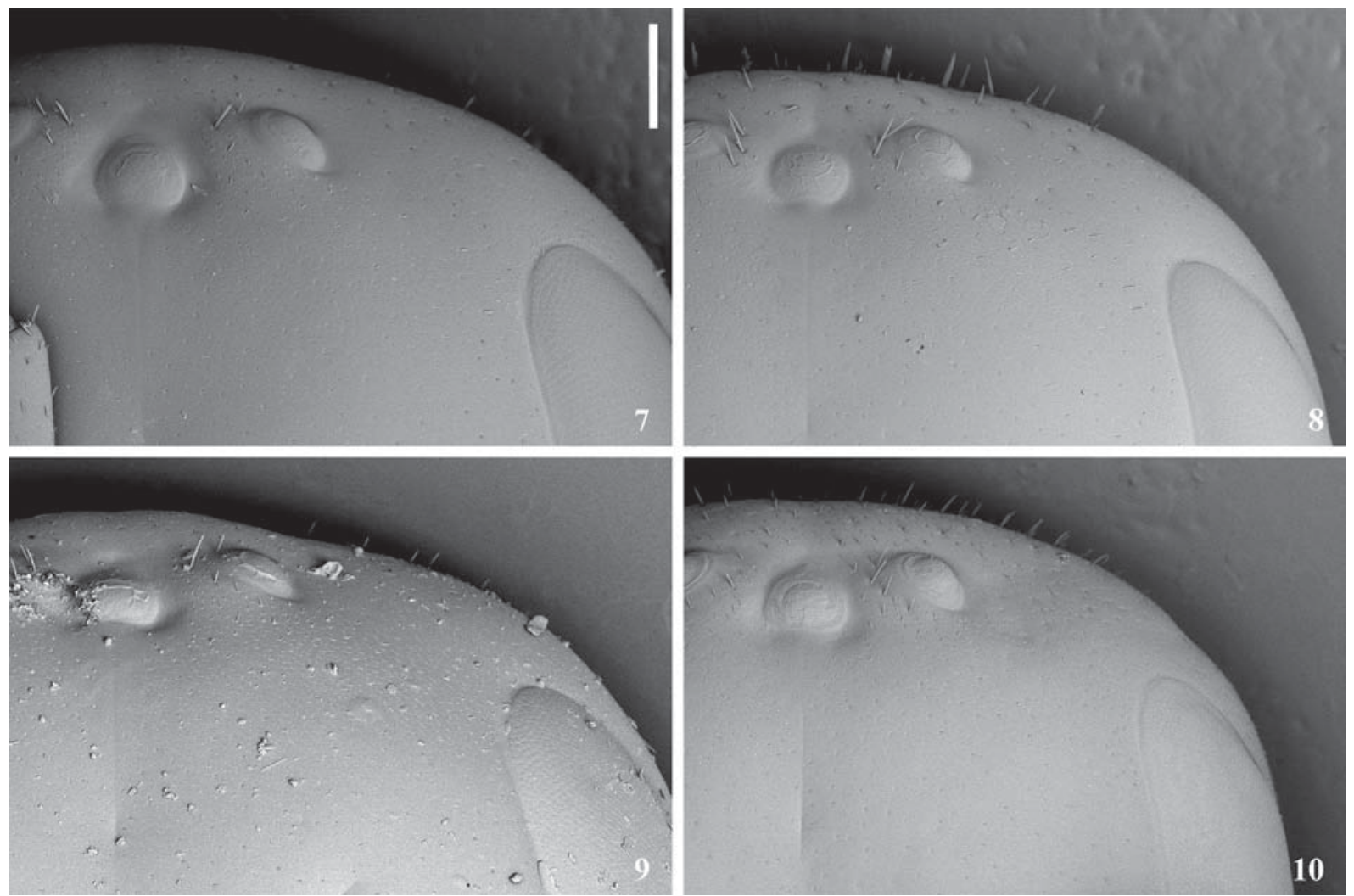

Figs. 7-10. Detalhe da fronte superior e vértice, vista frontal: 7. Lestrimelitta limao (Smith); 8. Lestrimelitta rufipes (Friese); 9. Lestrimelitta spinosa sp. nov.; 10. Lestrimelitta tropica sp. nov. Escala $=200 \mu \mathrm{m}$.

aproximadamente 2,5 vezes mais largo que longo $(1,08: 0,41)$; $1^{\circ}$. flagelômero um pouco mais longo que o $2^{\circ}$. $(0,18: 0,16)$, iguais na largura $(0,15: 0,15)$; distância entre os ocelos laterais em torno de 2 vezes o diâmetro do ocelo médio $(0,41: 0,20)$; área malar a metade do diâmetro do escapo $(0,07: 0,17)$; escutelo um pouco mais longo que largo $(0,49: 0,54)$; basitarsos médios aproximadamente 6 vezes mais longos que sua largura máxima $(0,84: 0,14)$; basitarsos posteriores aproximadamente 4 vezes mais longos que sua largura máxima $(0,90: 0,22)$ e 1,5 vezes mais largos que os médios $(0,22: 0,14)$; tíbias posteriores aproximadamente 2,5 vezes mais longas que sua largura máxima $(1,37: 0,53)$; contorno da abertura do espiráculo propodeal alongado, aproximadamente 4 vezes mais longo do que largo $(0,20: 0,05)$; esporão mesotibial curto $(0,12)$.

Variações. Algumas operárias de Rio Negro, Amazonas, e Ilha de Maracá, Roraima, apresentam cerdas a partir das laterais de T1 e o macho de Rio Negro apresenta cerdas a partir das laterais de $\mathrm{T} 2$.

Material-tipo examinado. Friese descreveu Trigona (Lestrimelitta) limao v. rufipes baseando-se em uma série de operárias e machos de Bauru, São Paulo, coletados por Ihering. Para estabilizar a taxonomia do gênero, designa-se aqui uma operária do AMNH como lectótipo, cujos dados são como segue: 'Brasil, São Paulo, Bahuru, 1899, Ihering, 47' (o número 47 escrito na lateral), 'acc 35178' e 'Lestrimelitta limao + 925 Friese det.'. Paralectótipos: 1 operária (AMNH), idem; 1 macho (AMNH), idem, exceto ' $\sigma^{\text {") }} ; 1$ macho (AMNH), '(etiqueta vermelha)', 'Brasil, São Paulo, Bahuru, 1897, Ihering, 47', e 'L. limao v. rufipes, ơ Friese det.' e 'TYPUS' (etiqueta laranja); 1 macho (ZMHB), 'Zool. Mus. Berlin' (etiqueta amarela), 'Brasil, São Paulo, Bahuru, 1899, Ihering, 47', 'Type' (etiqueta vermelha) e ' $\sigma$ ' limao v. rufipes, 1900 Frise det.' (a terminália foi removida do espécime e não se encontra junto a ele). No lectótipo, a seguinte etiqueta foi adicionada 'Lectotype, Trigona (Lestrimelitta) limao v. rufipes Friese, 1903, des. Marchi \& Melo, 2004'.

Material adicional examinado. BRASIL. Roraima: 1 operária (DZUP), 'Brasil: Roraima. Ilha de Maracá, 20-30.iii.1987, Luís S. Aquino, Arm. Malaise'; 1 operária (INPA), 'Brasil: Roraima, Rio Uraricoera, Ilha de Maracá, 20-30.iii.1987' e '21-30.xi.1987, J.A. Rafael e equipe'. Amazonas: 1 operária (DZUP), 'BRASIL: Amazonas, 26km NE Manaus, Reserva Ducke, 27-X-1988' e 'J.S. Rafael Arm. Suspensa, 1,5 metros'; 2 operárias e 1 macho (DZUP), 'Brasil, Amazonas, Rio Negro, Tapuruquara-Mirim, $0^{\circ} 25^{\prime} \mathrm{S} \quad 66^{\circ} 24^{\prime} \mathrm{W}$, 02.vii.1999, J.M.F. Camargo, ninho'; 1 operária (RPSP), 'RPSP 010048' e 'Comunidade São Simão, rio Andirá, AM, BRASIL, 0324’02"S 5656’13"W, 02.II.2001, Camargo leg.'; 19 operárias (RPSP), idem, exceto número de registro variando de 010049 a 010067. Pará: 2 operárias (DZUP, MPEG), 'Brasil, Pará, Tucuruí, Rio Tocantins, CANOAL (MATA), 31.III a 4.IV-1984' e 'Armadilha Suspensa, 1-6m'; 1 operária (MPEG), 'Brasil, Pará, Tucuruí, Rio Tocantins, CHIQUEIRÃO, 13-iv-1984' e 'Armadilha Suspensa, 1-6m'; 6 operárias (INPA), 'Itaituba (aldeia Saterê Maué, Comu. Vila Nova), Pará, Brasil, 28.VI.2000. Mata (9:15 hs) M. Glória, P. Assis coll.'; 1 macho (DZUP), 'Brasil, Pará, Tucuruí, Rio Tocantins, SAÚDE, 11 a 13-IV-1984'; 1 operária (RPSP), 'RPSP 010192' e 'Vila Nova, rio Andirá, PA, Brasil, 05.II.2001, 03³9’06"S 56²47'53"W, J.M.F. Camargo leg.'; 16 operárias (RPSP), idem, exceto número de registro variando de 010193 a 010208; 1 operária (MPEG), 'Brasil, Pará, Tucuruí, Rio Tocantins, CHIQUEIRÃO, 13-iv-1984' e 'Armadilha Malaise'; 1 operária (MPEG), 'Brasil, Pará, Serra Norte, Est. Manganês, 9.V.1984'; 2 operárias (MPEG), idem, exceto '12.V.1984' ; 1 operária (MPEG), idem, exceto '18.VI.1984' ; 1 operária (MPEG), idem, exceto ‘6.VII.1984' ; 2 operárias (MPEG), 'Brasil, Pará, Serra Norte, Est. N. 
Serraria, 7 a 10.IX.1983, Col. R. B. Neto, Arm. Malaise'; 1 operária (MPEG), 'Brasil, Pará, Serra Norte, Est. da Serraria, Arm. Malaise, 10 a 15.IX.1983'; 1 operária (MPEG), 'Belém, Utinga, 24-VI-1977' e 'Brasil, Pará, L. Hock'; 1 operária (MPEG), 'Brasil-Pará- Melgaço, Caxiuanã-ECPn, 02.V.1999, O. Silveira \& J. Dias' e 'Percurso 5, Arm. S. Malaise, Caxiuanã, ECFPn, 02.V.1999'. Maranhão: 13 operárias (DZUP), 'BARRA DO CORDA, Maranhão, BRASIL, 12.VI.1956. J.M. Uchoa'. Ceará: 17 operárias e 1 macho (DZUP), 'IBIAPINA, Ceará, BRASIL, 18.XII.1954, A.P. Soares'. Rondônia: 223 operárias (DZUP), 'PORTO VELHO, Guaporé, BRASIL, XII-1954'. Mato Grosso: 3 operárias (DZUP), 'Barra do Garças, MT. BRASIL, 10.24-I.1971, Col. Camargo'; 2 operárias (RPSP), idem; 2 operárias (DZUP), 'Três Lagoas MT. Brasil, x-1964, G.S. Dias'; 32 operárias (DZUP), 'Caceres-MT, Brasil - 19-X-61, F.M. Oliveira'; 1 operária (DZUP), 'SERRA DO RONCADOR, MT - R.S. Base Camp, BRASIL - 11/7/1968, Laroca \& Azevedo'; 1 operária (MPEG), 'Brasil, MT, Chap. Dos Guimarães, Colégio Agr. Buriti, 13 a 17-II-1986, Col. J. S. Gorayeb' e 'Armadilha Suspensa 1,6 m'. Tocantins: 2 operárias (RPSP), 'Mateiros, TO, Brasil, $46^{\circ} 18^{\prime} \mathrm{W} 10^{\circ} 27^{\prime} \mathrm{S}, 10.12$.VII.1995, $650 \mathrm{~m}$, Camargo; Pedro leg.' Bahia: 13 operárias e 4 machos (DZUP), 'IBIASSUCÊ, CACULE-BA, Brasil, 21-VIII-61, Salgado, Laroca'. Goiás: 17 operárias (DZUP), 'Brasil, Goiás, $2 \mathrm{~km} \mathrm{~W}$ de Teresina de Goiás, Fazenda Santa Tereza, 1347'43"S $47^{\circ} 17^{\prime} 39^{\prime \prime W}, 800 \mathrm{~m}, 03 . i v .2003$, Melo, Aguiar, Marchi e Gonçalves, ninho 1'; 8 operárias (DZUP), idem, exceto 'ninho 2'; 11 operárias (DZUP), idem, exceto 'ninho 3'. Minas Gerais: 1 operária (DZUP), 'São Romão, MG, Brasil, 8-XI-60, N.L. Marston'. Espírito Santo: 16 operárias (DZUP), ' SANTA TERESA-ES, BRASIL - 22/X/1966, C. Elias leg.'; 1 operária (UFMG), 'Reserva Florestal, C.V.R.D., 14864050' e 'Linhares: ES, BRASIL, 13/08/1996, J.S. Santos'. São Paulo: 1 operária (SEMK), 'BRASIL, Ribeirão Preto, São Paulo, 24 December 1971, C. D. Michener'. Paraná: 42 operárias (DZUP), 'Brasil, Mandirituba, Paraná, 1.II.2003, A. Pegoraro col.’; 1 macho (DZUP), idem, exceto '31.III.2003'. Santa Catarina: 2 operárias (DZUP), 'Brasilien, Nova Teutonia $\left(27^{\circ} 11^{\prime}\right.$ 'S $\left.52^{\circ} 23^{\prime} \mathrm{L}\right)$ Fritz Plaumann, VII.1950, 300-500m.' 3 operárias (SEMK), 'Santa Catarina, Nova Teutonia, Brazil, VII-28-1950, F. Plaumann'. Rio Grande do Sul: 65 operárias (DZUP), 'EREXIM-RS, Brasil, 27-11-65, F. Giacomel leg'; 26 operárias (DZUP), 'B. de COTEGIPE, R. Gr. S.-BRASIL, 15/I/ 1967, F. Giacomel leg'

Distribuição geográfica. Amplamente distribuída no Brasil (Fig. 31).

\section{Lestrimelitta ciliata sp. nov.}

(Fig. 29)

Diagnose. Cabeça com algumas cerdas curtas e finas na região interocelar; lobos pronotais e bordo anterior das tégulas com cerdas eretas longas; cerdas enegrecidas a partir das laterais de T1. Muito semelhante a L. limao, diferindo desta pela distribuição uniforme das cerdas em todo o bordo anterior do mesoscuto e laterais dos mesepisternos com cerdas eretas mais longas nos dois terços inferiores. $\mathrm{O}$ macho difere do macho de L. limao pela presença de cerdas curtas no vértice e cerdas eretas em todo bordo anterior do mesoscuto.

\section{Holótipo operária.}

Dimensões. Comprimento total aproximado: $5,19 \mathrm{~mm}$; comprimento das asas anteriores: $4,10 \mathrm{~mm}$; largura da cabeça: $2,00 \mathrm{~mm}$.

Cor do integumento. Predominantemente castanhoenegrecido, face ventral dos escapos e flagelos castanhos; mandíbulas castanho-avermelhadas, enegrecidas no bordo cortante e base; pernas, T1 e T2 castanho-avermelhados.
Membrana alar um pouco enfumada, pterostigma e veias acastanhadas.

Pilosidade. Microcerdas na face tão curtas como o diâmetro dos pontos, um pouco mais longas (2DP) nas genas; algumas cerdas conspícuas no ápice do escapo. Vértice com poucas cerdas eretas muito curtas e finas, restritas à região interocelar; cerdas esparsas semi-decumbentes curtas ao longo do rebordo pré-occipital. Lobos pronotais e bordo anterior das tégulas com cerdas eretas e enegrecidas $(0,10-0,12 \mathrm{~mm})$. Mesoscuto com cerdas eretas castanhas em todo o bordo anterior, em torno de $0,12 \mathrm{~mm}$ na porção mediana e um pouco mais longas, $0,18 \mathrm{~mm}$, nas laterais; cerdas mais curtas nos bordos laterais. Escutelo com algumas cerdas eretas curtas e finas no disco e no bordo posterior, cerdas castanhas um pouco encurvadas para cima, as mais longas com $0,25 \mathrm{~mm}$. Laterais dos mesepisternos com cerdas curtíssimas no terço superior e cerdas eretas castanhas de até $0,09 \mathrm{~mm}$ nos dois terços inferiores. Flancos do propódeo com pilosidade densa e ramificada, mas não tomentosa. Tíbias médias com algumas cerdas semi-decumbentes muito curtas na face externa; bordos anterior e posterior com cerdas mais longas nas extremidades apicais. Fêmures posteriores com cerdas enegrecidas uniformemente distribuídas em toda a face externa. Tíbias posteriores com cerdas castanhas praticamente do mesmo comprimento nos bordos anterior e posterior $(0,15 \mathrm{~mm})$, algumas com uma ramificação curta na parte mediana. Metassoma com cerdas enegrecidas a partir das laterais de $\mathrm{T} 1$; algumas cerdas muito curtas no bordo posterior de T3 e T4; T5 e T6 cerdosos.

Medidas e proporções. Cabeça mais larga do que longa e mais larga que o mesossoma $(2,02: 1,61: 1,54)$; órbitas internas divergentes inferiormente; $(1,32: 1,34)$; olhos mais longos que sua largura máxima $(1,22: 0,55)$; largura máxima dos olhos, em vista lateral, menor que a largura máxima das genas $(0,46: 0,62)$; clípeo aproximadamente 3,5 vezes mais largo que longo $(1,25: 0,37) ; 1^{\circ}$. flagelômero de aproximadamente 2 vezes mais longo que o $2^{\circ}$. $(0,16: 0,08)$, e um pouco maior na largura $(0,17: 0,16)$; distância entre os ocelos laterais aproximadamente 2 vezes o diâmetro do ocelo médio $(0,37: 0,17)$; área malar menor que o diâmetro do escapo $(0,11: 0,15)$; escutelo levemente mais largo que longo $(0,58: 0,49)$; basitarsos médios 6 vezes mais longos que sua largura máxima $(0,77: 0,12)$; basitarsos posteriores em torno de 2,5 vezes mais longos que largos $(0,72: 0,28)$ e aproximadamente 2 vezes mais largos que os médios $(0,28: 0,12)$; tíbias posteriores 3 vezes mais longas que sua largura máxima $(1,44: 0,43)$; contorno da abertura do espiráculo propodeal ovalado, aproximadamente 2,5 vezes mais longo do que largo $(0,19: 0,06)$; esporão mesotibial reduzido.

\section{Macho.}

Dimensões. Comprimento total aproximado: $6,37 \mathrm{~mm}$; comprimento das asas anteriores: $3,92 \mathrm{~mm}$; largura da cabeça: $2,11 \mathrm{~mm}$.

Cor do integumento. Predominantemente castanhoenegrecido, escapos, bordo posterior do clípeo, mandíbulas e pernas castanho-amarelados. Membrana alar como na operária. 
Pilosidade. Microcerdas na face tão curtas como o diâmetro dos pontos. Vértice com poucas cerdas eretas muito curtas e finas, na região interocelar e rebordo pré-occipital. Lobos pronotais e bordo anterior das tégulas com cerdas eretas e enegrecidas. Mesoscuto com cerdas eretas castanhas em todo o bordo anterior (em torno de $0,08 \mathrm{~mm}$ ), um pouco mais longas $(0,15 \mathrm{~mm})$ nas laterais; cerdas curtas nos bordos laterais. Escutelo com cerdas eretas curtas e finas no disco e mais longas bordo posterior. Laterais dos mesepisternos com cerdas curtíssimas no terço superior e cerdas eretas castanhas de até $0,09 \mathrm{~mm}$ nos dois terços inferiores. Flancos do propódeo com pilosidade bastante densa e ramificada. Tíbias médias com cerdas enegrecidas na face externa e nos bordos anterior e posterior. Fêmures posteriores com cerdas enegrecidas uniformemente distribuídas em toda a face externa. Tíbias posteriores com cerdas castanho-amareladas (em torno de 0,22 $\mathrm{mm}$ ) na face externa e nos bordos anterior e posterior, algumas com uma ramificação curta na parte mediana. Metassoma com cerdas enegrecidas $(0,10 \mathrm{~mm})$ a partir das laterais de $\mathrm{T} 1$; algumas cerdas muito curtas no bordo posterior de T3 e T4; T5 a T7 cerdosos.

Medidas e proporções. Cabeça mais larga do que longa e mais larga que o mesossoma $(2,11: 1,66: 1,61)$; órbitas internas convergentes inferiormente $(1,27: 1,17)$; olhos mais longos que sua largura máxima $(1,27: 0,59)$; largura dos olhos maior que a largura máxima das genas em vista lateral $(0,54: 0,29)$; clípeo aproximadamente 4 vezes mais largo que longo $(1,03: 0,25) ; 1^{\circ}$. flagelômero um pouco mais longo que o $2^{\circ}$. $(0,20: 0,15)$, iguais na largura $(0,16: 0,16)$; distância entre os ocelos laterais em torno de 2 vezes o diâmetro do ocelo médio $(0,39: 0,20)$; área malar menor que o diâmetro do escapo $(0,11: 0,17)$; escutelo tão largo quanto longo $(0,68: 0,68)$; basitarsos médios aproximadamente 6,5 vezes mais longos que sua largura máxima $(0,85: 0,13)$; basitarsos posteriores aproximadamente 3 vezes mais longos que sua largura máxima $(0,68: 0,23)$ e 1,5 vezes mais largos que os médios $(0,23: 0,13)$; tíbias posteriores aproximadamente 2,5 vezes mais longas que sua largura máxima $(1,52: 0,59)$; contorno da abertura do espiráculo propodeal ovalado, 2 vezes mais longo do que largo $(0,19: 0,09)$; esporão mesotibial reduzido.

Material-tipo. Holótipo operária (MPEG), 'Brasil, Pará, Tucuruí, Rio Tocantins, CHIQUEIRÃO, 13-IV-1984' e 'armadilha suspensa'. Parátipos: 1 operária (DZUP), com os mesmos dados do holótipo; 1 operária (MPEG), 'Brasil, Pará, Serra Norte, Manganês, 18 a 21.IX.1985', 'Armadilha Malaise' e 'Brasil, Pará, F. Ramos'; 1 macho (DZUP), 'Brasil, Pará, Serra Norte, Ig. Saloso, 17 a 20.8.84' e 'Armadilha Suspensa 20 m'; 1 operária (MPEG), 'Brasil, Pará, Primavera, Quatipuru, FAZ. FEITORIA,27 a 28.XI.1992', ' Brasil, J. A. Dias' e 'Armadilha Suspensa 1,6 m'; 1 macho (MPEG), 'Brasil, Pará, Primavera, Boa Vista, Ilha Arapiranga, 22 a 23.XI.1992, 'Brasil, Pará, J. Dias' e 'Armadilha Suspensa 1,6 m'.

Distribuição geográfica. Conhecida apenas do Estado do Pará (Fig. 29).

Etimologia. Do latim, ciliatus $=$ dotado de pilosidade nos bordos ou margens. Referente à distribuição uniforme das cerdas do bordo anterior do mesoscuto desta espécie.

\section{Lestrimelitta maracaia sp. nov.}

(Fig. 29)

Lestrimelitta limao; Camargo \& Moure (1989: 204, 208 [espécimes da Ilha de Maracá, Roraima]).

Diagnose. Cabeça com cerdas curtas e finas, restritas à região interocelar; órbitas internas paralelas; bordo anterior do mesoscuto com cerdas eretas longas nas laterais e algumas muito curtas na porção mediana; lobos pronotais e bordo anterior das tégulas com cerdas eretas longas. Difere de $L$. limao, L. spinosa $\mathbf{s p . ~ n o v . ~ e ~ L . ~ c i l i a t a ~ s p . ~ n o v . ~ p e l o s ~ s e g u i n t e s ~}$ caracteres: laterais dos mesepisternos com cerdas eretas nos dois terços inferiores, cerdas eretas apenas no terço posterior do escutelo, flancos do propódeo com pilosidade ramificada apenas próximo ao espiráculo e ausência de cerdas nas laterais de T1. Nos machos, laterais dos mesepisternos cerdosas, diferindo do macho de $L$. spinosa sp. nov. por apresentar as laterais de $\mathrm{T} 1$ com cerdas em torno de $0,10 \mathrm{~mm}$ e esporão mesotibial reduzido, porém visível (em torno de $0,05 \mathrm{~mm}$ ).

\section{Holótipo operária.}

Dimensões. Comprimento total aproximado: $6,37 \mathrm{~mm}$; comprimento das asas anteriores: $4,10 \mathrm{~mm}$; largura da cabeça: $2,11 \mathrm{~mm}$.

Cor do integumento. Predominantemente castanhoenegrecido, mandíbulas castanho-avermelhadas, enegrecidas no bordo cortante e base; coxas, trocanteres, extremidades dos fêmures e tarsos castanhos. Membrana alar um pouco enfumada, pterostigma e veias acastanhados.

Pilosidade. Microcerdas na face tão curtas como o diâmetro dos pontos, um pouco mais longa e densa nas genas. Vértice com poucas cerdas eretas muito finas e curtas (de até 0,06 $\mathrm{mm}$ ), restritas à região interocelar; cerdas curtas ao longo do rebordo pré-occipital. Escapos com algumas cerdas eretas, finas e amareladas (de 0,05 mm) no ápice. Bordo anterior do mesoscuto com cerdas eretas enegrecidas (em torno de 0,17 $\mathrm{mm}$ ) nas laterais e algumas cerdas muito curtas e finas na porção mediana; nos bordos laterais, cerdas curtas. Escutelo com cerdas eretas, a partir do terço posterior, as mais longas com $0,22 \mathrm{~mm}$ e um pouco encurvadas para cima no bordo posterior. Lobos pronotais com cerdas eretas e enegrecidas de aproximadamente $0,10 \mathrm{~mm}$; cerdas eretas amareladas no bordo anterior das tégulas de até $0,10 \mathrm{~mm}$. Laterais dos mesepisternos com cerdas eretas finas e acastanhadas $(0,08$ $0,10 \mathrm{~mm}$ ). Flancos do propódeo com pilosidade fina, curta, mais ramificada em torno do espiráculo propodeal. Tíbias médias com pilosidade decumbente fina mais longa que nas tíbias anteriores, com algumas cerdas acastanhadas semidecumbentes na face externa e cerdas castanhas curtas nos bordos anterior e posterior. Fêmures posteriores com cerdas castanhas (em torno de $0,07 \mathrm{~mm}$ ), uniformemente distribuídas em toda face externa. Tíbias posteriores com cerdas de até $0,20 \mathrm{~mm}$ no bordo posterior, algumas com uma ramificação curta na parte mediana e no bordo anterior um pouco mais curtas, finas semi-decumbentes e acastanhadas. Metassoma 
com microcerdas decumbentes e esparsas nas laterais de $\mathrm{T} 1$; cerdas eretas mais longas $(0,07 \mathrm{~mm})$ a partir das laterais de $\mathrm{T} 2$; $\mathrm{T} 3$ e T4 com microcerdas no bordo posterior; T5 e T6 cerdosos, cerdas com aproximadamente $0,16 \mathrm{~mm}$ em $\mathrm{T} 6$, algumas com um ou dois ramos subapicais.

Medidas e proporções. Cabeça mais larga do que longa e mais larga que o mesossoma $(2,11: 1,65: 1,66)$; órbitas internas paralelas $(1,44: 1,44)$; olhos 2 vezes mais longos que sua largura máxima $(1,27: 0,59)$; clípeo aproximadamente 3,5 vezes mais largo que longo $(1,32: 0,39) ; 1^{\circ}$. flagelômero um pouco mais longo $(0,15: 0,10)$ e mais largo que o $2^{\circ}$. $(0,16: 0,17)$; distância entre os ocelos laterais 2 vezes o diâmetro do ocelo médio $(0,39: 0,16)$; área malar um pouco menor que o diâmetro do escapo $(0,12: 0,13)$; escutelo mais largo que longo $(0,63: 0,54)$; basitarsos médios 4,5 vezes mais longos que largos $(0,77: 0,17)$; basitarsos posteriores 2,5 vezes mais longos que largos $(0,84: 0,33)$ e 2 vezes mais largos que os médios $(0,33: 0,17)$; tíbias posteriores aproximadamente 3 vezes mais longas que sua largura máxima $(1,44: 0,50)$; contorno da abertura do espiráculo propodeal ovalado, aproximadamente 2 vezes mais longo do que largo $(0,18: 0,08)$; esporão mesotibial reduzido $(0,03)$.

\section{Macho.}

Dimensões. Tamanho aproximado do corpo: $6,08 \mathrm{~mm}$; largura da cabeça: $2,15 \mathrm{~mm}$; comprimento das asas anteriores: $4,21 \mathrm{~mm}$.

Cor do integumento. Castanho-enegrecido; bordo posterior do clípeo amarelado; mandíbulas castanhas, enegrecidas na base e ápice; labro, face ventral dos escapos, flagelos e pernas castanhos. Membrana alar como na operária.

Pilosidade. Microcerdas na face tão curtas como o diâmetro dos pontos, um pouco mais longas (2DP) nas genas. Vértice com poucas cerdas eretas enegrecidas curtas $(0,07 \mathrm{~mm})$, na região interocelar; cerdas enegrecidas ao longo do rebordo pré-occipital. Lobos pronotais com cerdas eretas castanhas e longas $(0,14 \mathrm{~mm})$ e no limite com os mesepisternos, pilosidade plumosa amarelada muito curta e densa. Bordo anterior das tégulas com cerdas de aproximadamente $0,07 \mathrm{~mm}$. Bordo anterior do mesoscuto com cerdas castanhas muito finas, curtas e esparsas na porção mediana e cerdas mais espessas e longas (aproximadamente $0,16 \mathrm{~mm}$ ) nas laterais; nos bordos laterais, cerdas mais curtas (em torno de $0,08 \mathrm{~mm}$ ). Escutelo com algumas cerdas acastanhadas finas de aproximadamente $0,13 \mathrm{~mm}$ no disco; no bordo posterior, cerdas amareladas um pouco encurvadas para cima medindo $0,29 \mathrm{~mm}$. Laterais dos mesepisternos com cerdas eretas castanho-amareladas de aproximadamente $0,15 \mathrm{~mm}$. Flancos do propódeo com pilosidade esbranquiçada decumbente com poucas ramificações compactas e curtas. Tíbias médias com pilosidade decumbente um pouco mais longa que nas anteriores, cerdas amareladas $(0,16 \mathrm{~mm})$ nos bordos anteriores, posteriores e algumas cerdas castanhas, curtas e semi-decumbentes na face externa. Fêmures posteriores com cerdas uniformemente distribuídas em toda a face externa. Tíbias posteriores com cerdas castanho-amareladas no bordo posterior $(0,12 \mathrm{~mm})$, algumas com uma ramificação na parte mediana; no bordo anterior, mais curtas e encurvadas; cerdas semi-decumbentes em toda a face externa. Metassoma com cerdas castanhas a partir das laterais de T1, aumentando em densidade e comprimento em direção ao último tergo; T4 e T5 com algumas cerdas muito curtas e esparsas no disco, T6 e T7 cerdosos.

Medidas e proporções. Cabeça mais larga do que longa e mais larga que o mesossoma $(2,15: 1,56: 1,52)$; órbitas internas convergentes inferiormente $(1,27: 1,17)$; olhos mais longos que sua largura máxima $(1,60: 0,65)$; largura dos olhos maior que a largura máxima das genas em vista lateral $(0,57: 0,31)$; clípeo aproximadamente 2,5 vezes mais largo que longo $(1,08: 0,45)$; $1^{\circ}$. flagelômero um pouco mais longo que o $2^{\circ}$. $(0,17: 0,14)$ e iguais na largura $(0,16: 0,16)$; distância entre os ocelos laterais aproximadamente 2 vezes o diâmetro do ocelo médio $(0,46: 0,22)$; área malar menor que o diâmetro do escapo $(0,11: 0,15)$; escutelo um pouco mais largo que longo $(0,58: 0,55)$; basitarsos médios 7 vezes mais longos que sua largura máxima $(0,84: 0,12)$; basitarsos posteriores aproximadamente 5 vezes mais longos que sua largura máxima $(0,77: 0,19)$ e mais largos que os médios $(0,19: 0,12)$; tíbias posteriores aproximadamente 2,5 vezes mais longas que sua largura máxima (1,44:0,55); contorno da abertura do espiráculo propodeal ovalado, aproximadamente 2,5 vezes mais longo do que largo $(0,21: 0,08)$; esporão mesotibial reduzido (aproximadamente 0,05 ).

Material-tipo. Holótipo operária (RPSP), '15', 'Ilha de Maracá - RR, Brasil, 5-10/10/1987, Lúcio A. O. Campos, Márcio V. B. Garcia’ e 'Lestrimelitta limao (Smith, 1863) Det. Camargo 1987'. Parátipos: Amazonas: 1 macho (DZUP), 'Manaus, Amazonas, Brasil, junho.1959, C. Elias' e 'armadilha suspensa'. Roraima: 1 operária (DZUP), com os mesmos dados do holótipo; 1 operária (INPA), 'BRASIL - Roraima, Rio Uraricoera, Ilha de Maracá, 02-13.v.1987' e ‘Eng. J. A. Rafael Arm. de Malaise'; 1 macho (DZUP), idem, exceto '21-30.xi.1987'.

Distribuição geográfica. Conhecida apenas da região de Manaus até o norte de Roraima (Fig. 29).

Etimologia. Em referência ao local de coleta do holótipo, Ilha de Maracá.

\section{Lestrimelitta similis sp. nov.}

(Fig. 32)

Diagnose. Esta espécie separa-se de L. limao, L. rufa, L. sulina sp. nov., $L$. tropica $\mathbf{s p . ~ n o v . , ~} L$. spinosa $\mathbf{s p .}$ nov., $L$. maracaia sp. nov. e L. ciliata $\mathbf{s p . ~ n o v . , ~ p e l o ~ f o r m a t o ~ d o ~}$ espiráculo propodeal (alongado), pela ausência de cerdas eretas longas nos lobos pronotais e tégulas. Difere de L. rufipes pelos seguintes caracteres: bordo anterior do mesoscuto com cerdas eretas apenas nas laterais; metassoma com cerdas eretas mais longas a partir das laterais de T4. Macho sem cerdas eretas no vértice; tíbias médias com cerdas longas e densas na face externa e bordo posterior; cerdas das tíbias médias e posteriores espatuladas no ápice. Difere do macho de $L$. glabrata pela presença de cerdas curtas nas laterais do bordo anterior do mesoscuto e pelo metassoma com cerdas mais longas a partir das laterais de $\mathrm{T} 3$.

\section{Holótipo operária.}



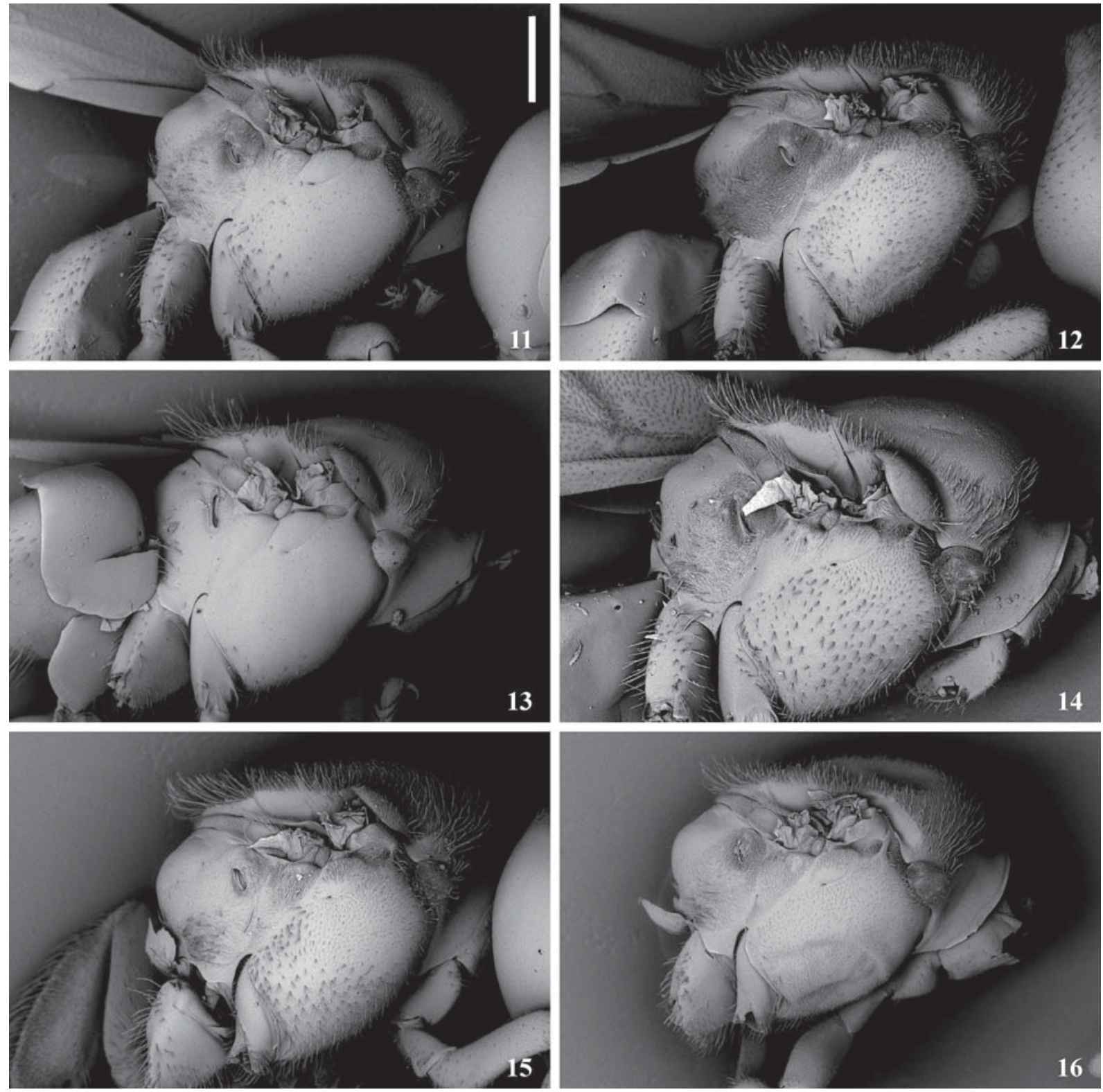

Figs. 11-16. Mesossoma, vista lateral: 11. Lestrimelitta limao (Smith); 12. Lestrimelitta rufa (Friese); 13. Lestrimelitta rufipes (Friese); 14. Lestrimelitta spinosa $\mathbf{s p . ~ n o v . ; ~ 1 5 . ~ L e s t r i m e l i t t a ~ s u l i n a ~} \mathbf{s p}$. nov.; 16. Lestrimelitta tropica $\mathbf{s p}$. nov. Escala $=500 \mu \mathrm{m}$.

Dimensões. Comprimento total aproximado: $6,37 \mathrm{~mm}$; comprimento das asas anteriores: 4,51 mm; largura da cabeça: $2,30 \mathrm{~mm}$.

Cor do integumento. Predominantemente castanho-escuro; face ventral dos escapos e flagelos castanho-claros; mandíbulas castanho-avermelhadas, enegrecidas no bordo anterior; pernas castanho-avermelhadas. Membrana alar fracamente enfumada, pterostigma e veias alares castanhoclaros.

Pilosidade. Microcerdas na face tão curtas como o diâmetro dos pontos. Vértice com algumas cerdas eretas castanhas e curtas (em torno de $0,05 \mathrm{~mm}$ ), cerdas mais longas e densas no rebordo pré-occipital. Escapos com cerdas eretas conspícuas apenas no ápice. Lobos pronotais e tégulas sem cerdas eretas. Mesoscuto com cerdas eretas nas laterais do bordo anterior (de aproximadamente $0,15 \mathrm{~mm}$ ), algumas com ápice espatulado; nos bordos laterais, cerdas eretas próximo às axilas. Escutelo com cerdas eretas no disco, em torno de $0,20 \mathrm{~mm}$ e no bordo posterior, de até $0,40 \mathrm{~mm}$. Laterais dos mesepisternos com microcerdas esparsas; cerdas eretas longas restritas à porção ventral. Flancos do propódeo com pilosidade densa, porém curtíssima e fina. Tíbias médias sem cerdas na face externa; nos bordos anterior e posterior, cerdas castanho-amareladas curtas. Fêmures posteriores sem cerdas eretas na face externa, cerdas restritas ao bordo anterior e ápice. Tíbias posteriores com as cerdas do bordo posterior castanhas, de até $0,40 \mathrm{~mm}$; no bordo anterior, cerdas em torno de $0,15 \mathrm{~mm}$. Metassoma com cerdas curtas e enegrecidas nas laterais de T4 $(0,05 \mathrm{~mm})$, mais longas $(0,20 \mathrm{~mm})$ no bordo posterior e laterais de $\mathrm{T} 5$; $\mathrm{T} 6$ cerdoso, com cerdas de $0,20 \mathrm{~mm}$. 
Medidas e proporções. Cabeça mais larga do que longa e mais larga que o mesossoma (2,30: 1,96:1,71:); órbitas internas paralelas $(1,51: 1,51)$; olhos em torno de 2 vezes mais longos que sua largura máxima (1,32:0,59); largura dos olhos menor que a largura das genas em vista lateral $(0,49: 0,59)$; clípeo aproximadamente 3 vezes mais largo que longo (1,05:0,38); $1^{\mathrm{o}}$. flagelômero 2 vezes mais longo que o $2^{\circ}$. $(0,17: 0,08)$, iguais na largura $(0,16: 0,16)$; distância entre os ocelos laterais aproximadamente 2 vezes o diâmetro do ocelo médio $(0,34: 0,17)$; área malar praticamente igual ao diâmetro do escapo $(0,12: 0,12)$; escutelo mais largo do que longo $(0,60: 0,48)$; basitarsos médios aproximadamente 4 vezes mais longos que sua largura máxima $(0,65: 0,14)$; basitarsos posteriores 3 vezes mais longos que sua largura máxima $(0,79: 0,26)$ e 1,8 vezes mais largos que os médios $(0,26: 0,14)$; tíbias posteriores 3 vezes mais longas que sua largura máxima $(1,61: 0,48)$; contorno da abertura do espiráculo propodeal 4 vezes mais longo do que largo $(0,22: 0,05)$; esporão mesotibial curto (em torno de 0,10$)$.

Macho.

Dimensões. Tamanho aproximado do corpo: $6,56 \mathrm{~mm}$; largura da cabeça: $2,10 \mathrm{~mm}$; comprimento das asas anteriores: 4,06 mm.

Cor do integumento. Predominantemente castanho-escuro; bordo posterior do clípeo, parte ventral dos escapos, flagelos, áreas paroculares inferiores, tégulas, pernas, T1 e T2 castanhos. Membrana alar como na operária.

Pilosidade. Microcerdas na face tão curtas como o diâmetro dos pontos. Vértice sem cerdas eretas, algumas cerdas curtíssimas e esparsas no rebordo pré-occipital. Laterais do bordo anterior do mesoscuto com algumas cerdas muito curtas $(0,15 \mathrm{~mm})$. Escutelo com cerdas nos dois terços posteriores, as mais longas com até $0,50 \mathrm{~mm}$. Mesepisternos com cerdas eretas apenas na parte ventral. Flancos do propódeo com pilosidade curta e fina. Tíbias médias com cerdas escuras longas, densas, espessas e espatuladas no ápice (em torno de $0,50 \mathrm{~mm}$ no bordo posterior e $0,20 \mathrm{~mm}$ de comprimento na face externa). Fêmures posteriores com cerdas enegrecidas mais longas apenas no ápice. Tíbias posteriores com cerdas amareladas bastante longas, em torno de 0,50 $\mathrm{mm}$ no bordo posterior, algumas espatuladas no ápice; cerdas semidecumbentes na face externa e um pouco mais curtas no bordo anterior. Metassoma com cerdas castanho-enegrecidas curtíssimas $(0,05 \mathrm{~mm})$ nas laterais posteriores de T2; cerdas mais longas $(0,15 \mathrm{~mm})$ e espessas nas laterais de T3; cerdas de até 0,50 mm nas laterais e porção mediana de T4, T5 e T6.

Medidas e proporções. Cabeça mais larga do que longa e mais larga que o mesossoma $(2,10: 1,62: 1,62)$; órbitas internas convergentes inferiormente $(1,32: 1,13)$; olhos mais longos que sua largura máxima $(1,27: 0,60)$; largura dos olhos maior que a largura máxima das genas em vista lateral $(0,50: 0,31)$; clípeo aproximadamente 2,5 vezes mais largo que longo (1,08:0,41); $1^{\circ}$. flagelômero um pouco mais longo que o $2^{\circ}$. $(0,18: 0,16)$, igual na largura $(0,15)$; distância entre os ocelos laterais em torno de 2 vezes o diâmetro do ocelo médio $(0,41: 0,20)$; área malar metade do diâmetro do escapo $(0,07: 0,17)$; escutelo um pouco mais longo que largo $(0,54: 0,49)$; basitarsos médios aproximadamente 6 vezes mais longos que sua largura máxima $(0,84: 0,14)$; basitarsos posteriores aproximadamente 4 vezes mais longos que sua largura máxima $(0,90: 0,22)$; basitarsos posteriores 1,5 vezes mais largos que os médios $(0,22: 0,14)$; tíbias posteriores aproximadamente 2,5 vezes mais longas que sua largura máxima $(1,37: 0,53)$; contorno da abertura do espiráculo propodeal alongado, aproximadamente 4 vezes mais longo do que largo $(0,20: 0,05)$; esporão mesotibial curto $(0,12)$.

Material-tipo. Holótipo: operária (MPEG), 'Brasil, Pará, Paragominas, Faz. Cachoeira do Rio Vermelho, 18 a 21-I-1991', 'Brasil, Pará, P. Tadeu' e 'Armadilha Suspensa 1,6 m'. Parátipos: 1 operária (DZUP), com os mesmos dados do holótipo; 1 macho (MPEG), idem, exceto 'Brasil, Pará, B. Mascarenhas'; 1 macho (DZUP), idem; 2 machos (MPEG), idem, exceto '15-18-I-1991' e 'Brasil, Pará, J. Dias'; 1 operária (MPEG), 'Brasil, Pará, Belém, Floresta APEG, 10 a 14-II-1983, col. L. S. Gorayeb e equipe' e 'Arm. Suspensa 1,6 m'; 2 operárias (DZUP, MPEG), 'Brasil, Pará, Tucuruí, Rio Tocantins, Arm. Inter. 13 a 21-IV1985; 1 operária (MPEG), 'Brasil, Pará, Mun. Barcarena, Caripi, 01²9’40" S 4842’35" W, Mata; 13 a 22-XI-2001, Armadilha Malaise’ e 'L. S. Gorayeb, A. Tavares, N. Bittencourt, J. O. Dias'; 1 operária e 1 macho (MPEG), 'Brasil, PA - Melgaço, Caxiuanã, ECFPn, 19.XI.1998, O. Silveira, J. Pena col.' e 'Arm. S. Malaise, SMC-29, Rio Caxiuanã, 19.XI.1998'.

Distribuição geográfica. Conhecida apenas do Estado do Pará (Fig. 32).

Etimologia. Do latim, similis = semelhante; pela semelhança a L. rufipes e L. glabrata.

\section{Lestrimelitta spinosa sp. nov.}

(Figs. 5, 9, 14, 20, 26, 29)

Lestrimelitta limao; Schwarz (1938: 451 [espécimes de Yarikita, Guiana, e de Trinidad]); Schwarz (1948: 191 [espécimes de Yarikita, Guiana, e de Trinidad]).

Diagnose. Cabeça com cerdas curtas e finas, restritas à região interocelar; órbitas internas paralelas; bordo anterior do mesoscuto com cerdas eretas nas laterais e poucas cerdas muito curtas na porção mediana; lobos pronotais e bordo anterior das tégulas com cerdas eretas longas e espessas. Esta espécie difere de L. limao pela presença de cerdas eretas longas e espessas nas laterais dos mesepisternos. Muito semelhante a L. maracaia sp. nov., separando-se desta por apresentar cerdas enegrecidas e espessas nas laterais dos mesepisternos e pela presença de cerdas curtíssimas e esparsas nas laterais deT1. Os machos desta espécie diferem dos machos de L. maracaia sp. nov. pela presença de cerdas eretas, porém finas curtas e esparsas nas laterais de T1 e pelo esporão mesotibial extremamente reduzido (não visível).

\section{Holótipo operária.}

Dimensões. Comprimento total aproximado: 5,49 $\mathrm{mm}$; comprimento das asas anteriores: 4,21 mm; largura da cabeça: 2,16 mm.

Cor do integumento. Predominantemente castanhoenegrecido, mandíbulas castanho-avermelhadas, enegrecidas no bordo cortante e base; coxas, trocanteres, extremidades dos fêmures e tarsos castanhos; asas hialinas um pouco 

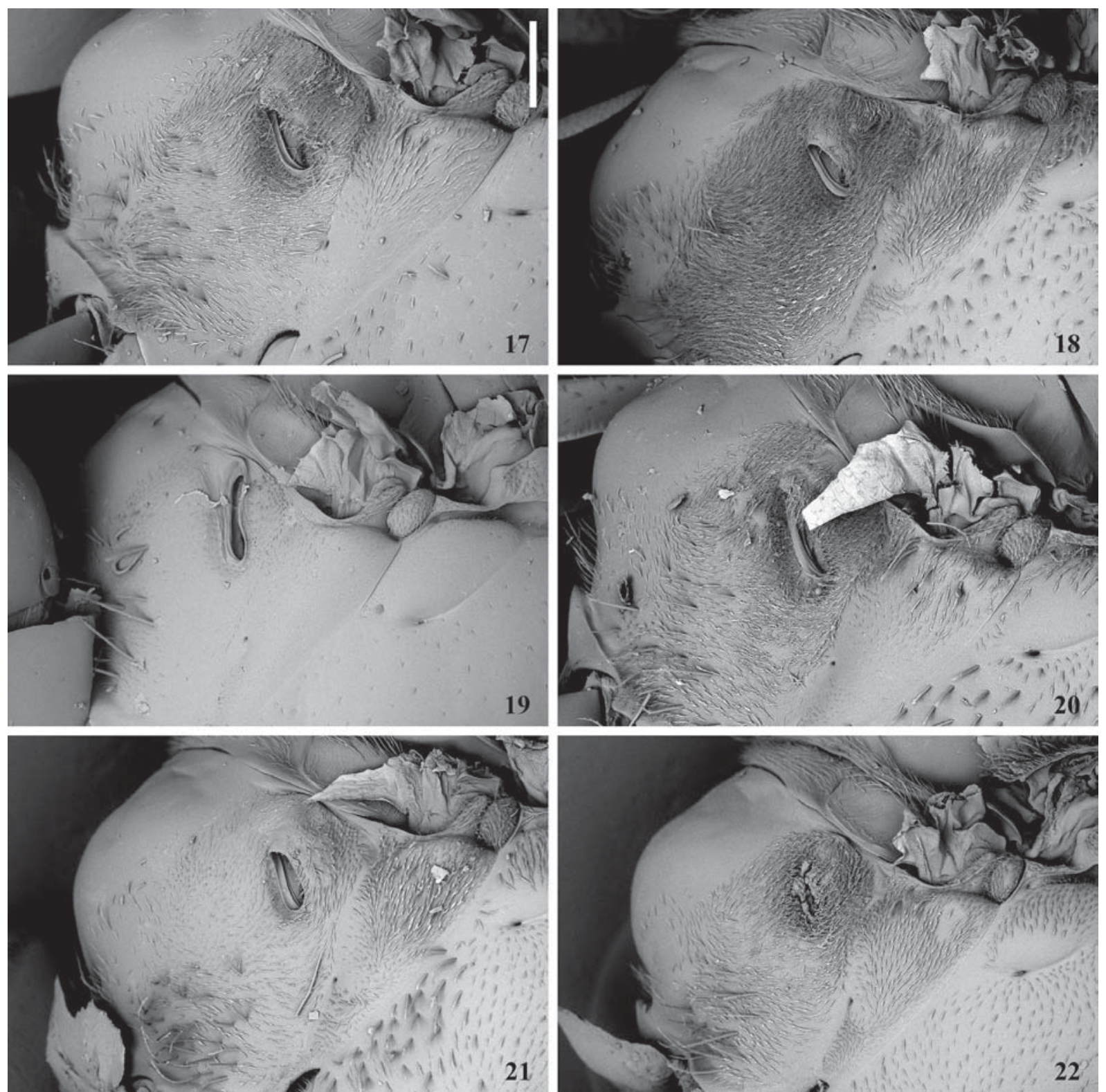

Figs. 17-22. Propódeo, em vista lateral, mostrando detalhes da pilosidade: 17. Lestrimelitta limao (Smith); 18. Lestrimelitta rufa (Friese); 19. Lestrimelitta rufipes (Friese); 20. Lestrimelitta spinosa $\mathbf{s p}$. nov.; 21. Lestrimelitta sulina $\mathbf{s p .}$ nov.; 22. Lestrimelitta tropica $\mathbf{s p}$. nov. Escala $=200$ $\mu \mathrm{m}$.

escurecidas, pterostigma e veias alares acastanhados.

Pilosidade. Microcerdas na face tão curtas como o diâmetro dos pontos, um pouco mais longa nas genas. Vértice com poucas cerdas eretas muito finas e curtas (de até $0,06 \mathrm{~mm}$ ), na região interocelar; cerdas esparsas semi-decumbentes muito curtas (aproximadamente $0,035 \mathrm{~mm}$ ) ao longo do rebordo préoccipital. Escapo com algumas cerdas eretas, finas e amareladas $(0,05 \mathrm{~mm})$ no ápice. Mesoscuto com cerdas eretas enegrecidas no bordo anterior, mais longas e densas nas laterais (aproximadamente $0,25 \mathrm{~m}$ ) e poucas cerdas muito curtas e finas na porção mediana; bordos laterais com cerdas curtas, em torno de $0,06 \mathrm{~mm}$. Escutelo com cerdas eretas enegrecidas, algumas com ramificações curtas e compactas no terço superior; no disco, curtas e no bordo posterior mais espessas, longas $(0,25 \mathrm{~mm})$ e um pouco encurvadas para cima. Lobos pronotais com cerdas eretas e enegrecidas, as mais longas e espessas no bordo anterior (em torno de $0,17 \mathrm{~mm}$ ). Bordo anterior das tégulas com algumas cerdas eretas amareladas (com cerca de $0,15 \mathrm{~mm}$ ). Laterais dos mesepisternos com cerdas eretas, enegrecidas e espessas $(0,06-0,07 \mathrm{~mm})$. Flancos do propódeo com pilosidade esbranquiçada, longa, relativamente densa e um pouco ramificada, mas não tomentosa. Tíbias médias com pilosidade decumbente fina mais longa que nas tíbias anteriores, com algumas cerdas acastanhadas semidecumbentes na face externa e cerdas castanhas curtas nos bordos anterior e posterior. Fêmures posteriores com cerdas eretas castanhas uniformemente distribuídas em toda face externa. Tíbias posteriores com cerdas enegrecidas e bastante 
espessas (em torno de $0,17 \mathrm{~mm}$ ) no bordo posterior; cerdas um pouco mais curtas, finas, acastanhadas e encurvadas no bordo anterior. Metassoma com algumas cerdas eretas, acastanhadas, finas e curtas (em torno de $0,05 \mathrm{~mm}$ ) nas laterais de $\mathrm{T} 1$; mais longas e densas $(0,10 \mathrm{~mm})$ nas laterais de $\mathrm{T} 2 \mathrm{e}$ em torno de 0,15 mm nas laterais de T3 a T5; bordo posterior de T4 e de T5 com cerdas muito curtas e esparsas; T6 com cerdas enegrecidas e espessas, de aproximadamente $0,20 \mathrm{~mm}$.

Medidas e proporções. Cabeça mais larga do que longa e mais larga que o mesossoma $(2,16: 1,62: 1,62)$; órbitas internas paralelas (1,37:1,37); olhos mais longos que sua largura máxima $(1,22: 0,60)$; largura máxima dos olhos, em vista lateral, menor que a largura das genas $(0,53: 0,60)$; clípeo aproximadamente 3,5 vezes mais largo que longo $(1,32: 0,38) ; 1^{\circ}$. flagelômero 2 vezes mais longo que o $2^{\circ}$. $(0,19: 0,09)$ e iguais na largura $(0,20: 0,20)$; distância entre os ocelos laterais quase 2 vezes o diâmetro do ocelo médio $(0,32: 0,18)$; área malar menor que o diâmetro do escapo $(0,12: 0,14)$; escutelo mais largo que longo $(0,53: 0,41)$; basitarsos médios em torno de 5 vezes mais longos que largos $(0,69: 0,14)$; basitarsos posteriores um pouco mais que 2 vezes mais longos que largos $(0,77: 0,33)$ e 2 vezes mais largos que os médios $(0,34: 0,17)$; tíbias posteriores aproximadamente 3 vezes mais longas que sua largura máxima (1,44:0,53); contorno da abertura do espiráculo propodeal ovalado, aproximadamente 2,5 vezes mais longo do que largo (0,18:0,07); esporão mesotibial extremamente reduzido.

\section{Macho.}

Dimensões. Comprimento total aproximado: 6,56 mm; comprimento das asas anteriores: $3,82 \mathrm{~mm}$; largura da cabeça: $2,10 \mathrm{~mm}$.

Cor do integumento. Predominantemente enegrecido; bordo posterior do clípeo e labro amarelados; mandíbulas, escapos, flagelos, lobos pronotais e pernas castanhoavermelhados.

Pilosidade. Poucas cerdas eretas muito finas e curtas na região interocelar. Lobos pronotais e bordo anterior das tégulas com cerdas eretas e enegrecidas. Mesoscuto com cerdas eretas no bordo anterior, mais longas e densas nas laterais (em torno de $0,25 \mathrm{~m}$ ) e poucas cerdas muito curtas e finas na porção mediana e nos bordos laterais. Escutelo com algumas cerdas eretas curtas e enegrecidas no disco, e no bordo posterior mais espessas, longas $(0,25 \mathrm{~mm})$ e um pouco encurvadas para cima. Laterais dos mesepisternos com cerdas eretas, enegrecidas e espessas (de até 0,14 mm). Flancos do propódeo com pilosidade esbranquiçada, longa, densa e ramificada, mas não tomentosa. Tíbias médias com cerdas enegrecidas na face externa e cerdas castanhas mais longas nos bordos anterior e posterior. Fêmures posteriores com cerdas eretas castanhas $(0,12 \mathrm{~mm})$ em toda face externa. Tíbias posteriores com cerdas acastanhadas (em torno de $0,30 \mathrm{~mm}$ ), alguma com ramificações curtas. Metassoma com algumas cerdas eretas, acastanhadas, finas e curtas $(0,05 \mathrm{~mm})$ nas laterais de $\mathrm{T} 1$; nas laterais de $\mathrm{T} 2$, cerdas mais longas e densas $(0,12 \mathrm{~mm}), \mathrm{T} 3$ a T7 com cerdas aumentando um pouco em densidade e comprimento.

Medidas e proporções. Cabeça mais larga do que longa e mais larga que o mesossoma $(2,10: 1,71: 1,76)$; órbitas internas convergentes inferiormente $(1,27: 1,18)$; olhos mais longos que sua largura máxima $(1,32: 0,64)$; largura dos olhos maior que a largura máxima das genas em vista lateral $(0,55: 0,31)$; clípeo aproximadamente 2,5 vezes mais largo que longo (1,08:0,39); $1^{\circ}$. flagelômero mais longo que o $2^{\circ}$. $(0,18: 0,12)$, iguais na largura $(0,15: 0,15)$; distância entre os ocelos laterais em torno de 2 vezes o diâmetro do ocelo médio $(0,41: 0,22)$; área malar menor que o diâmetro do escapo $(0,09: 0,13)$; escutelo quase tão largo quanto longo $(0,59: 0,63)$; basitarsos médios aproximadamente 5 vezes mais longos que sua largura máxima $(0,63: 0,12)$; basitarsos posteriores aproximadamente 4 vezes mais longos que sua largura máxima $(1,03: 0,23)$ e 2 vezes mais largos que os médios $(0,23: 0,12)$; tíbias posteriores aproximadamente 2,5 vezes mais longas que sua largura máxima $(1,52: 0,59)$; contorno da abertura do espiráculo propodeal ovalado, 2 vezes mais longo do que largo $(0,20: 0,10)$; esporão mesotibial extremamente reduzido.

Material-tipo. Holótipo: operária (DZUP), 'Lago Caetano, R. Trombetas, 10.03.98, F. A. J. Peralta'. Parátipos: 17 operárias (DZUP, AMNH), 'TRINIDAD, W. I., Arima Valley, 800-1200 ft., Feb. 10-22, 1964' e 'J. G. Rozen \& P. Wygodzinsky Collectors'; 3 operárias, 4 machos e 3 rainhas (DZUP, AMNH), 'SAN RAFAEL, Trinidad, BWI, 26-july-1945', 'R.G. Donald Coll. A174' e 'Lestrimelitta limao Smith, Det. R.G. Donald'; 1 operária (AMNH), 'Trinidad, 4243 V-35, Fitzgerald' e 'Lestrimelitta limao (Smith), Det. Schwarz + '; 1 operária (AMNH), '52400 a', 'Arima Valley, Trinidad, BWI, 3-II, 1952' e 'Gift of New York Zoo. Soc. Dept. Tropical Research, William Beebe, Dir.'; 1 operária (AMNH), idem, exceto a etiqueta de número, '10-III, 1952' e 'lights'; 1 operária (AMNH), idem, exceto '31-III, 1952' e '52440 a'; 1 operária (AMNH), idem, exceto '14-III, 1952 e '52436'; 1 operária (AMNH), idem, exceto a etiqueta de número e '2-IV, 1952'.

Distribuição geográfica. Conhecida apenas da região do baixo Trombetas, AM, Brasil e Trinidad (Fig.29).

Etimologia. Do latim, spinosus $=$ dotado de espinhos, em referência à presença de cerdas espessas nos lobos pronotais, bordo anterior das tégulas e laterais dos mesepisternos.

\section{Lestrimelitta sulina sp. nov.}

(Figs. 15, 21, 27, 29)

Lestrimelitta limao; Camargo \& Moure (1989: 204 [espécimes de Urussanga, Santa Catarina]).

Diagnose. Cabeça com cerdas eretas enegrecidas no vértice; lobos pronotais e bordo anterior das tégulas com cerdas eretas longas. L. sulina sp. nov e L. tropica sp. nov., apresentam cerdas esbranquiçadas nas pontas. Difere de L. tropica $\mathbf{s p .}$ nov e $L$. rufa (Friese) pelos seguintes caracteres: as cerdas eretas das laterais dos mesepisternos nos dois terços inferiores; pilosidade dos flancos do propódeo fina, não ramificada e curta e metassoma com cerdas apenas em T6. Macho com as laterais dos mesepisternos totalmente cerdosas e metassoma com cerdas apenas em T7, portanto difere do macho de $L$. tropica sp. nov. Difere do macho de L. rufa Friese pelo metassoma com cerdas apenas nos tergos apicais e pilosidade dos flancos do propódeo curta, fina e esparsa. 

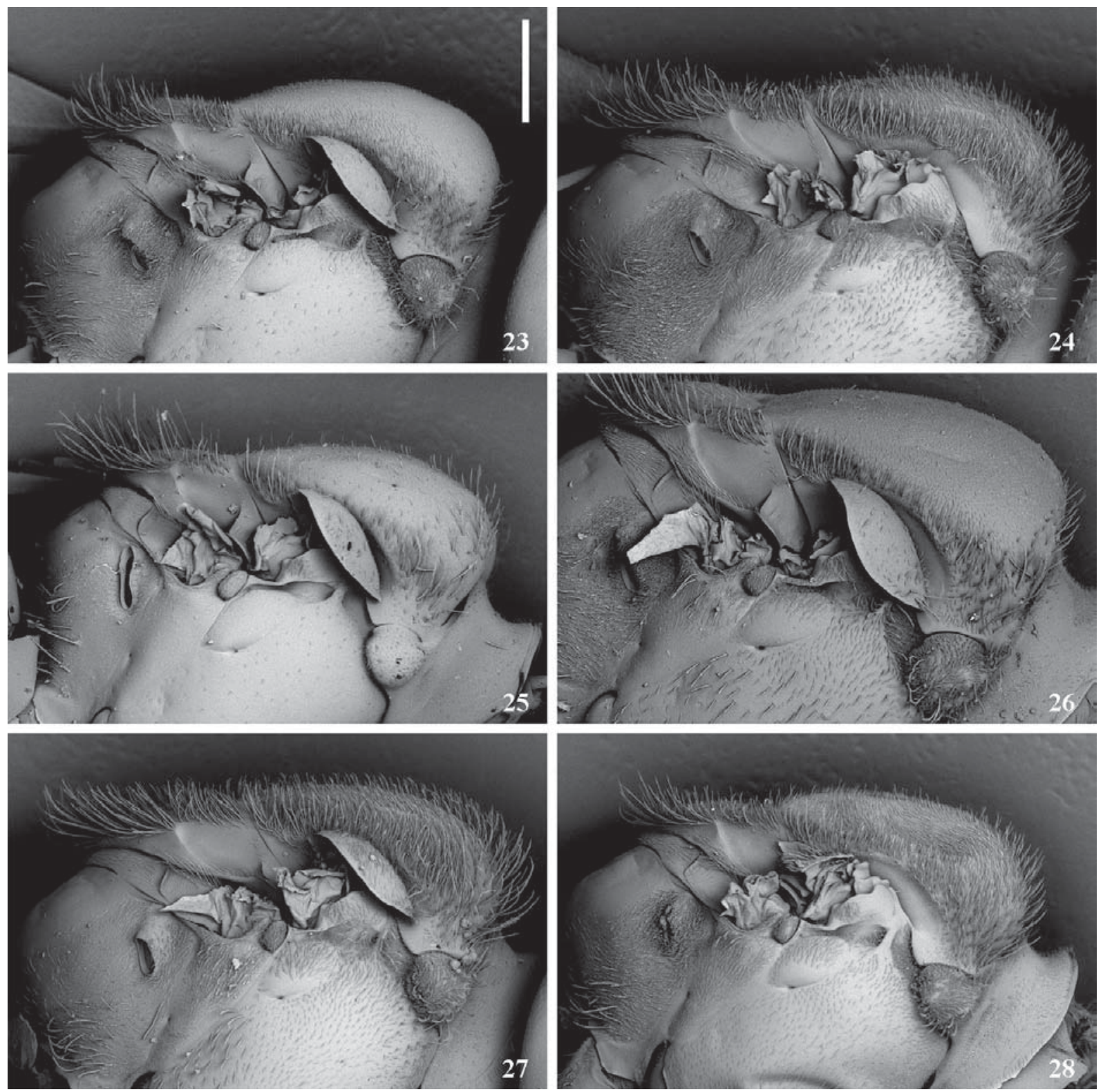

Figs. 23-28. Mesoscuto, vista lateral: 23. Lestrimelitta limao (Smith); 24. Lestrimelitta rufa (Friese); 25. Lestrimelitta rufipes (Friese); 26. Lestrimelitta spinosa $\mathbf{s p .}$ nov.; 27. Lestrimelitta sulina sp. nov.; 28. Lestrimelitta tropica sp. nov. Escala $=400 \mu \mathrm{m}$.

\section{Holótipo operária.}

Dimensões. Comprimento do corpo: $6,80 \mathrm{~mm}$; largura máxima da cabeça: $2,20 \mathrm{~mm}$; comprimento das asas anteriores: $4,30 \mathrm{~mm}$.

Cor do integumento. Predominantemente enegrecido; face ventral e base da face dorsal dos escapos castanhoavermelhadas; flagelos castanhos; mandíbulas castanhoavermelhadas, porém com o bordo cortante e a base enegrecidos; trocanteres e tarsos castanhos. Membrana alar fracamente enfumada, pterostigma e veias castanho-escuros.

Pilosidade. Microcerdas na face tão curtas como o diâmetro dos pontos, um pouco mais longas na área malar e genas, mais esparsa nas áreas paroculares. Escapos com cerdas eretas conspícuas apenas no ápice $(0,05 \mathrm{~mm})$. Vértice com cerdas eretas enegrecidas (de até $0,09 \mathrm{~mm}$ ) e um pouco mais curtas ao longo do rebordo pré-occipital. Lobos pronotais e parte anterior das tégulas com cerdas eretas castanho-enegrecidas e longas (em torno de $0,15 \mathrm{~mm}$ ). Mesoscuto com cerdas eretas enegrecidas com as pontas esbranquiçadas, as mais longas nos bordos laterais (na altura da metade posterior das tégulas) com $0,25 \mathrm{~mm}$, algumas com ramificações curtas e compactas próximas ao ápice; mais curtas no disco (aproximadamente $0,07 \mathrm{~mm}$ ). Escutelo com algumas cerdas eretas acastanhadas no disco e cerdas um pouco encurvadas para cima (com cerca de $0,25 \mathrm{~mm}$ ) no bordo posterior. Laterais dos mesepisternos com cerdas eretas amareladas, relativamente esparsas, de aproximadamente $0,11 \mathrm{~mm}$ a partir da metade inferior. Flancos do propódeo com pilosidade muito fina, curta e esparsa, alguns pêlos com poucas ramificações mais próximos ao espiráculo propodeal. Tíbias médias com pilosidade decumbente fina mais 
longa que nas tíbias anteriores; face externa com algumas cerdas enegrecidas curtas; nos bordos anterior e posterior, cerdas castanhas e curtas. Fêmures posteriores com cerdas enegrecidas não uniformemente distribuídas, mais curtas e esparsas na porção central da face externa. Tíbias posteriores com cerdas castanhas com a ponta esbranquiçada (de até $0,32 \mathrm{~mm}$ ), algumas com uma ou duas ramificações curtas, no bordo posterior e mais curtas $(0,20 \mathrm{~mm})$ no bordo anterior. T1 a T5 praticamente glabros, T6 com cerdas eretas castanhoenegrecidas finas de aproximadamente $0,22 \mathrm{~mm}$.

Medidas e proporções. Cabeça mais larga do que longa e mais larga que o mesossoma $(2,18: 1,68: 1,77)$; órbitas internas levemente divergentes inferiormente $(1,42: 1,44)$; olhos mais longos que sua largura máxima $(1,25: 0,60)$; largura máxima das genas maior que a largura dos olhos em vista lateral $(0,62: 0,36)$; clípeo aproximadamente 3 vezes mais largo que longo $(1,34: 0,38) ; 1^{\circ}$. flagelômero aproximadamente 2 vezes mais longo que o $2^{\circ}$. $(0,11: 0,19)$, iguais na largura $(0,17)$; distância entre os ocelos laterais pouco mais que 2,0 vezes o diâmetro do ocelo médio $(0,42: 0,16)$; área malar igual ao diâmetro do escapo $(0,12: 0,12)$; escutelo mais largo que longo $(0,69: 0,50)$; basitarsos médios em torno de 5 vezes mais longos que sua largura máxima $(0,72: 0,14)$; basitarsos posteriores aproximadamente 3 vezes mais longos que sua largura máxima $(0,82: 0,29)$ e 2 vezes mais largos que os médios $(0,29: 0,14)$; tíbias posteriores quase 3 vezes mais longas que sua largura máxima $(1,42: 0,50)$; espiráculo propodeal ovalado, aproximadamente 2 vezes mais longo do que largo $(0,16: 0,09)$; esporão mesotibial extremamente reduzido.

\section{Macho.}

Dimensões. Tamanho aproximado do corpo: 7,15 mm; largura máxima da cabeça: 1,94 mm; comprimento das asas anteriores: $3,82 \mathrm{~mm}$.

Cor do integumento. Predominantemente enegrecido; faixa estreita no bordo posterior do clípeo amarelada; labro, mandíbulas, base dos escapos, pernas anteriores, ápice das tíbias posteriores e tarsos castanhos. Membrana alar fracamente enfumada, pterostigma e veias alares castanhoescuros.

Pilosidade. Microcerdas na face tão curtas como o diâmetro dos pontos; escapos com cerdas eretas conspícuas apenas no ápice. Vértice com cerdas eretas castanhoenegrecidas $(0,12 \mathrm{~mm})$ e um pouco mais curtas ao longo do rebordo pré-occipital. Lobos pronotais e metade anterior das tégulas com algumas cerdas eretas enegrecidas de aproximadamente $0,12 \mathrm{~mm}$. Mesoscuto com cerdas eretas castanho-enegrecidas, algumas com as pontas esbranquiçadas, com $0,20 \mathrm{~mm}$ no bordo anterior e aproximadamente $0,14 \mathrm{~mm}$ no disco; escutelo com cerdas eretas, algumas com a ponta esbranquiçada, um pouco encurvadas para cima, de até $0,30 \mathrm{~mm}$ no bordo posterior e um pouco mais curtas e eretas no disco. Laterais dos mesepisternos com cerdas eretas castanhas de até $0,10 \mathrm{~mm}$. Flancos do propódeo com pilosidade muito fina, curta e pouco ramificada. Tíbias médias com cerdas amareladas de aproximadamente $0,15 \mathrm{~mm}$ nos bordos anteriores e posteriores. Fêmures posteriores com cerdas enegrecidas não uniformemente distribuídas, mais curtas e esparsas na porção central da face externa e mais longas $(0,14 \mathrm{~mm})$ próximas ao ápice. Tíbias posteriores com cerdas castanho-amareladas (algumas com ramificações finas na parte mediana) de aproximadamente $0,32 \mathrm{~mm}$ no bordo posterior, semidecumbentes na face externa, mais curtas e encurvadas no bordo anterior. Metassoma com T1 a T6 praticamente glabros; cerdas enegrecidas nas laterais e bordo posterior de $\mathrm{T} 7 \mathrm{com}$ até $0,18 \mathrm{~mm}$.

Medidas e proporções. Cabeça mais larga do que longa e mais larga que o mesossoma $(1,94: 1,58: 1,16)$; órbitas internas convergentes inferiormente $(1,22: 1,08)$; olhos mais longos que sua largura máxima $(1,20: 0,55)$; largura dos olhos maior que a largura máxima das genas em vista lateral $(0,50: 0,33)$; clípeo quase 2,5 vezes mais largo que longo $(0,91: 0,38) ; 1^{\circ}$. flagelômero um pouco mais longo que o $2^{\circ}$. $(0,14: 0,13)$ e um pouco mais estreito $(0,15: 0,16)$; distância entre os ocelos laterais 2 vezes o diâmetro do ocelo médio $(0,44: 0,22)$; área malar $1 / 3$ do diâmetro do escapo $(0,05: 0,15)$; escutelo mais largo que longo $(0,68: 0,54)$; basitarsos médios 7 vezes mais longos que sua largura máxima $(0,84: 0,12)$; basitarsos posteriores 3,5 vezes mais longos que sua largura máxima $(0,77: 0,22)$ e quase 2 vezes mais largos que os médios $(0,22: 0,12)$; tíbias posteriores em torno de 3 vezes mais longas que sua largura máxima $(1,46: 0,53)$; contorno da abertura do espiráculo propodeal ovalado, aproximadamente 2,5 vezes mais longo do que largo $(0,19: 0,07)$; esporão mesotibial extremamente reduzido.

Material-tipo. Holótipo: operária (DZUP), 'Brasil, Paraná, Curitiba, Jd. das Américas, 13.iii.2002, G. Melo \& P. Marchi'. Parátipos: 6 operárias (DZUP, RPSP, SEMK), com os mesmos dados do holótipo; 1 macho (DZUP), 'Brasil, Paraná, Curitiba, Largo da Ordem, 12.xi.2000, G. A. R. Melo'; 1 macho (DZUP), 'Brasil, Paraná, Curitiba, 7.ix.2004 (atacando ninho de mandaçaia), M. O. Silva e F. B. Matos'; 4 operárias (DZUP), 'Brasil, Paraná, Curitiba, Centro, 22.iii.2002, P. Marchi \& F. Oliveira'; 2 operárias (DZUP), 'Brasil, Paraná, Av. João Gualberto, 20.viii.2001, J. F. Santos-Filho'; 1 operária (DZUP), 'Curitiba, 900m, Paraná-Brasil, 25-1-1969, Dept. ZOO. leg’; 1 operária (DZUP), 'CURITIBA-PR, Brasil - VI-61, S. Laroca'; 6 operárias (AMNH), 'BRASIL, Rolandia, Paraná, April 1948' e ‘A. Maller Coll. Frank Johnson Donor'.

Material adicional examinado. BRASIL. Paraná: 1 operária (DZUP), 'Rio Negro, PR, X-53, M. White'; 20 operárias (DMHN), 'CURITIBA-PR (Rua Itacolomi, 6- Portão), 04-IV-1997, MALKOWSKI \& CAMARGO leg' e 'ASSOCIAÇÃO PARANAENSE DE APICULTORES'; 1 operária (DMHN), 'CURITIBA- PR, APA-STA. CÂNDIDA, 15-X-1997, MALKOWSKI, S.R.; 2 operárias (DZUP), 'S. José Pinhais - PR, Brasil (Br 277 - Km 54), 03-10. XII.1984, C. I. I. F. (Malaise)'; 71 operárias (DZUP), 'Piraquara-Paraná, Set-Out. 1950, $900 \mathrm{mts}$. Pe. J. S. Moure'; 3 operárias (DZUP), 'Brasil-Paraná, Guarapuava, leg: Bazilio, S. 15/06/1994'; 2 operárias (DZUP), 'Brasil, Paraná, Prudentópolis, 20.VI.2003, Lidiane Scariot leg.' e 'Ninho da casa do Sr. Carlos Chocioi'. Santa Catarina: 6 operárias (DZUP), 'Brasilien, Nova Teutônia, $27^{\circ} .11^{\prime}$ B. $52^{\circ} .23^{\prime}$ I, Fritz Plaumann, 300 $500 \mathrm{~m}$, IX 1952'; 5 operárias, idem, exceto 'VI 1953'; 1 operária (DZUP), 'Nova Teutônia, SC, Brasil IX-55, F. PLAUMANN'; 1 operária, idem, exceto '11/12/55'; 1 operária (SEMK), 'Brazil, Santa Catarina, Nova Teutonia, 5.feb.1955 (F. Plauman)'; 3 operárias (SEMK), 'Nova Teutonia, Santa Catarina, Brazil, XII-1952, F. Plaumann'; 16 operárias (RPSP), 'Urussanga, SC, BRASIL, II.1971, col. Camargo'; 1 macho (AMNH), idem; 2 machos (AMNH), 'Brasil, Blumenau, 1897, Virgil' e 


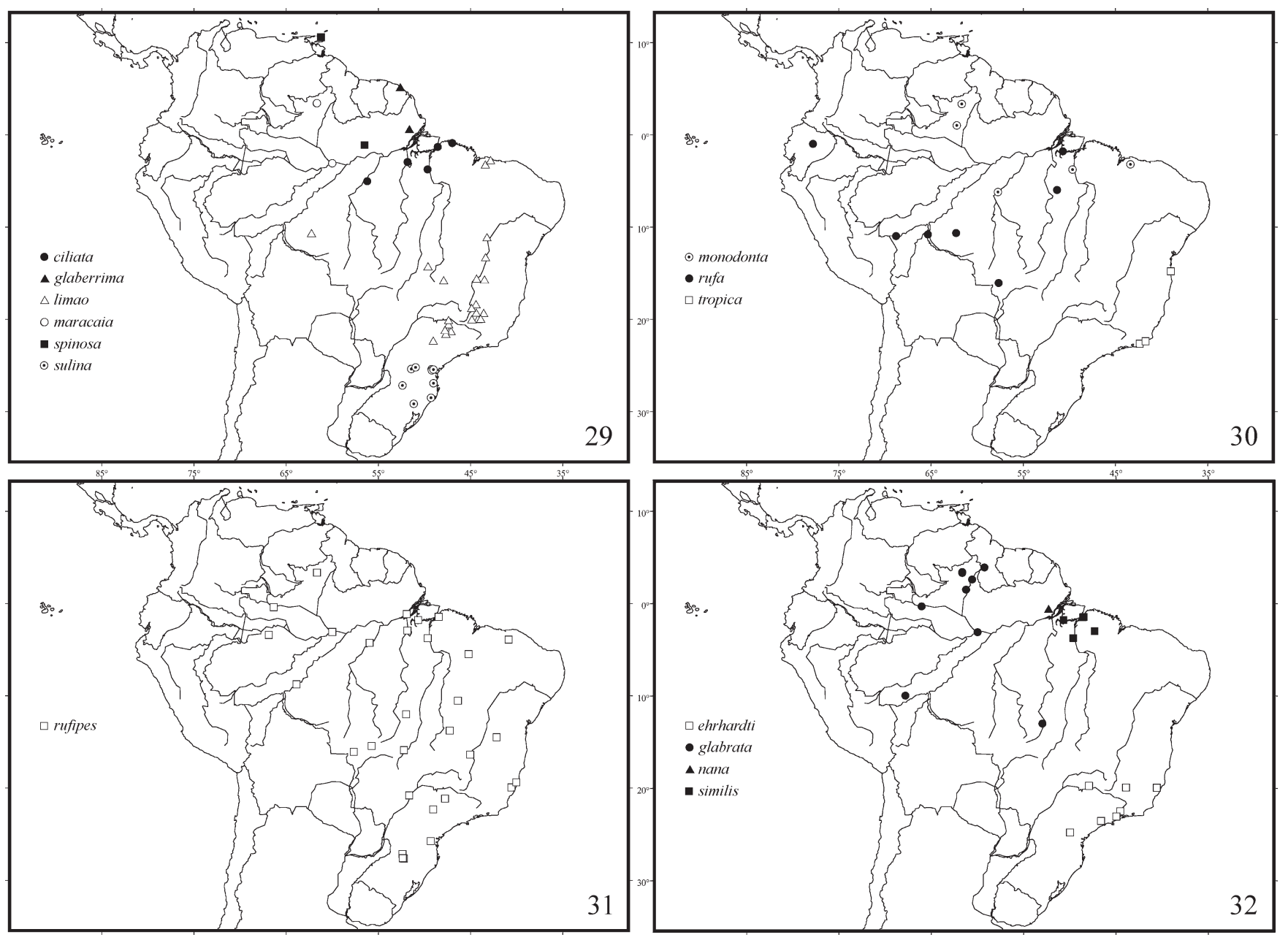

Figs. 29-32 . Registros geográficos das espécies de Lestrimelitta presentes no Brasil.

'acc 35178'. Rio Grande do Sul: 2 operárias (DZUP), IMIGRANTES - RS, I/1996, Brasil, MATERIAL DE NINHO, RÓNSIG, ARI'; 6 operárias (DZUP), 'Caxias, R.G.S.'; 9 operárias (AMNH), 'Colony 431, Caxias, Rio Grande do Sul. P. Nogueira-Neto collector, Brazil'.

Distribuição geográfica. Restrita à região Sul do Brasil (Fig. 29).

Etimologia: O nome refere-se à área de ocorrência da espécie.

\section{Lestrimelitta tropica sp. nov.}

(Figs. 6, 10, 28, 30)

Diagnose. Cabeça com cerdas eretas no vértice; lobos pronotais e bordo anterior das tégulas com cerdas eretas longas; mesoscuto cerdoso e, assim como em L. sulina $\mathbf{s p .}$ nov., as cerdas do mesoscuto e escutelo são esbranquiçadas na ponta, porém mais curtas e esparsas, além de outros caracteres que as diferem como a pilosidade ramificada e densa nos flancos do propódeo, os mesepisternos com cerdas eretas apenas na parte ventral e metassoma com cerdas apenas nas laterais de T5 e em T6. Nos machos, o metassoma apresenta cerdas apenas nas laterais de T5, laterais e bordo posterior de T6 e em T7, diferindo do macho de L. sulina sp. nov. pelas laterais dos mesepisternos, com cerdas eretas apenas na parte ventral e flancos do propódeo com pilosidade longa e ramificada, mas não tomentosa.

\section{Holótipo operária.}

Dimensões. Comprimento total aproximado: $5,90 \mathrm{~mm}$; comprimento das asas anteriores: $4,30 \mathrm{~mm}$; largura da cabeça: $2,20 \mathrm{~mm}$

Cor do integumento. Predominantemente castanhoenegrecido; mandíbulas castanho-avermelhadas enegrecidas na base e bordo cortante; flagelos, parte ventral dos escapos, coxas, trocanteres e tarsos castanhos; fêmures e dois terços basais das tíbias posteriores castanho-avermelhados; lobos pronotais e tégulas com manchas castanhas; duas manchas castanhas semi-circulares no terço anterior do escutelo; T1 e $\mathrm{T} 2$ castanhos. Membrana alar um pouco enfumada, pterostigma e veias acastanhados.

Pilosidade. Microcerdas na face tão curtas como o diâmetro dos pontos, um pouco mais longas (2DP) nas genas. Vértice com cerdas eretas enegrecidas (até $0,10 \mathrm{~mm}$ ), mais curtas e esparsas ao logo do rebordo pré-occipital. Lobos pronotais com algumas cerdas eretas castanhas com $0,10 \mathrm{~mm}$; tégulas com cerdas enegrecidas, as mais longas com $0,13 \mathrm{~mm}$ no bordo 
anterior. Mesoscuto com cerdas eretas castanhas, algumas com poucas ramificações (compactas), esbranquiçadas na ponta; as do bordo anterior com aproximadamente $0,17 \mathrm{~mm}$ e mais curtas no disco. Escutelo com cerdas enegrecidas longas no bordo posterior (em torno de $0,24 \mathrm{~mm}$ ) e encurvadas para cima, algumas esbranquiçadas na ponta; no disco, cerdas eretas mais curtas e esparsas. Laterais dos mesepisternos com poucas cerdas eretas apenas na parte ventral. Flancos do propódeo com pilosidade curta, muito ramificada e densa, mas não tomentosa (alguns pêlos com duas, outros com até seis ramificações bem finas). Tíbias médias com pilosidade decumbente fina na face externa, mais longa que nas tíbias anteriores e cerdas castanhas curtas nos bordos anterior e posterior. Fêmures posteriores com cerdas uniformemente distribuídas na face externa. Tíbias posteriores com cerdas castanho-amareladas no bordo posterior (as mais longas com $0,22 \mathrm{~mm}$ ), algumas com poucas ramificações curtas na parte mediana; no bordo anterior, poucas cerdas muito curtas e esparsas. Metassoma com T1 a T4 praticamente glabros, cerdas eretas presentes nas laterais de T5; T6 com cerdas de até $0,25 \mathrm{~mm}$.

Medidas e proporções. Cabeça mais larga do que longa e mais larga que o mesossoma $(2,20: 1,71: 1,80)$; órbitas internas levemente divergentes inferiormente $(1,39: 1,42)$; olhos mais longos que sua largura máxima (1,20:0,60); largura máxima dos olhos, em perfil, menor que a largura máxima das genas (051:0,62); clípeo 3 vezes mais largo que longo $(1,30: 0,39) ; 1^{\circ}$. flagelômero quase 2 vezes mais longo que o $2^{\circ}$. $(0,16: 0,09)$, e praticamente iguais na largura $(0,17: 0,18)$; distância entre os ocelos laterais aproximadamente 2 vezes o diâmetro do ocelo médio $(0,38: 0,17)$; área malar igual ao diâmetro do escapo $(0,12: 0,12)$; escutelo mais largo que longo $(0,65: 0,48)$; basitarsos médios em torno de 5 vezes mais longos que largos $(0,79: 0,14)$; basitarsos posteriores 2,5 vezes mais longos que largos $(0,84: 0,34)$ e aproximadamente 2 vezes mais largos que os médios $(0,34: 0,14)$; tíbias posteriores aproximadamente 3 vezes mais longas que sua largura máxima $(1,49: 0,53)$; contorno da abertura do espiráculo propodeal ovalado, aproximadamente 3 vezes mais longo do que largo (0,19:0,06); esporão mesotibial curto $(0,11)$, com forma triangular (alargado na base) acastanhado.

\section{Macho.}

Dimensões. Comprimento total aproximado: 5,49 mm; comprimento das asas anteriores: $3,92 \mathrm{~mm}$; largura da cabeça: $1,97 \mathrm{~mm}$.

Cor do integumento. Predominantemente castanhoenegrecido; metade posterior do clípeo castanha, mandíbulas castanhas, enegrecidas no bordo cortante; face ventral dos escapos, flagelos, lobos pronotais e pernas castanhos. Membrana alar um pouco enfumada, pterostigma e veias acastanhados.

Pilosidade. Microcerdas na face tão curtas como o diâmetro dos pontos, um pouco mais longa (2DP) nas genas. Vértice com cerdas eretas enegrecidas (em torno de $0,10 \mathrm{~mm}$ ) e um pouco mais curtas ao longo do rebordo pré-occipital. Lobos pronotais com cerdas eretas castanhas, esbranquiçadas nas pontas, de $0,10 \mathrm{~mm}$, no bordo anterior das tégulas, cerdas de $0,15 \mathrm{~mm}$. Mesoscuto com cerdas eretas castanhas, esbranquiçadas na ponta, de aproximadamente $0,15 \mathrm{~mm}$ no bordo anterior e um pouco mais curtas e esparsas no disco. Escutelo com cerdas castanhas longas, em torno de $0,25 \mathrm{~mm}$ e encurvadas para cima no bordo posterior; no disco, mais curtas $(0,18 \mathrm{~mm})$ e eretas. Laterais dos mesepisternos com cerdas eretas apenas na parte ventral. Flancos do propódeo com pilosidade muito ramificada e densa, mas não tomentosa. Tíbias médias com cerdas castanhas curtas nos bordos anterior e posterior e algumas cerdas curtas, semi-decumbentes na face externa. Fêmures posteriores com cerdas eretas uniformemente distribuídas na face externa. Tíbias posteriores com cerdas castanho-amareladas na face externa e no bordo posterior, as mais longas com $0,23 \mathrm{~mm}$, algumas com poucas ramificações curtas na parte mediana; bordo anterior com cerdas um pouco mais curtas. Metassoma com T1 a T4 praticamente glabros; cerdas castanho-amareladas nas laterais de $\mathrm{T} 5$; laterais e bordo posterior de T6; T7 cerdoso.

Medidas e proporções. Cabeça mais larga do que longa e mais larga que o mesossoma $(1,97: 0,72: 0,89)$; órbitas internas convergentes inferiormente $(1,42: 1,03)$; olhos mais longos que sua largura máxima $(1,27: 0,59)$; largura máxima dos olhos maior que a largura das genas em vista lateral $(0,50: 0,31)$; clípeo aproximadamente 5 vezes mais largo que longo $(2,06: 0,40) ; 1^{\circ}$. flagelômero um pouco mais longo que o $2^{\circ}$. $(0,16: 0,12)$, praticamente iguais na largura $(0,17: 0,16)$; distância entre os ocelos laterais aproximadamente 2 vezes o diâmetro do ocelo médio $(0,37: 0,19)$; área malar 4 vezes menor que o diâmetro do escapo $(0,04: 0,15)$; escutelo mais largo que longo $(0,31: 0,24)$; basitarsos médios aproximadamente 8 vezes mais longos que largos $(0,87: 0,10)$; basitarsos posteriores cerca de 2 vezes mais longos que largos $(0,84: 0,34)$ e aproximadamente 4 vezes mais largos que os médios $(0,69: 0,18)$; tíbias posteriores 2,5 vezes mais longas que sua largura máxima $(1,39: 0,53)$; espiráculo propodeal ovalado, aproximadamente 3 vezes mais longo do que largo $(0,19: 0,06)$; esporão mesotibial curto.

Material-tipo. Holótipo operária (DZUP), 'Brasil, Rio de Janeiro, Silva Jardim, Faz. Iguapê, 8.iii.2003, S.L. Pinto leg.' Parátipos: Ceará: 34 operárias e 3 machos (DZUP), 'Brasil, Ceará, Localidade desconhecida, Prof. Melquiades Pinto Paiva coll. (Universidade do Ceará, Instituto de Biologia Marinha)'. Bahia: 1 operária (DZUP), 'Brasil, Bahia, Ilhéus, Campus da UESC, 10.i.2003, G. Melo \& M. Costa'. Rio de Janeiro: 12 operárias (DZUP, RPSP, UFV), com os mesmos dados do holótipo; 2 operárias (RPSP), 'Brasil, Rio de Janeiro: Macaé Sana. Em ninho, 22¹9'S/42¹0’W, 14/JAN/1999. M. L. Oliveira' e 'RPSP 991777; 2 operárias (RPSP), idem, exceto 'RPSP 991778'; 2 operárias (DZUP), idem, exceto 'RPSP 991779'.

Distribuição geográfica. Conhecida dos Estados do Ceará, Bahia e Rio de Janeiro (Fig. 30). O material proveniente do Ceará não apresenta localidade de coleta e, portanto, este registro foi omitido no mapa.

Etimologia. Do grego, tropica $=$ vivendo nos trópicos.

Agradecimentos. Ao Conselho Nacional de Desenvolvimento 
Científico e Tecnológico (CNPq) pelos auxílios concedidos. Ao Dr. Alexandre Pires Aguiar (Museu de Zoologia, Universidade de São Paulo) e Dra. Danúncia Urban (Universidade Federal do Paraná, UFPR) pelas discussões enriquecedoras. Ao Dr. João M. F. Camargo (Universidade de São Paulo), Dr. Lucio A. O. Campos (Universidade Federal de Viçosa) e Dr. Orlando Tobias Silveira (Museu Paraense Emílio Goeldi) pela doação de espécimes. Às Instituições e Curadores das coleções, pelo empréstimo do material estudado.

\section{REFERÊNCIAS}

Almeida, M. C. \& S. Laroca. 1882. Sobre o macho de Lestrimelitta ehrhardti Friese, espécie cleptobiótica, rara, do Brasil (Apidae, Meliponinae). Dusenia 13: 41-45.

Ayala, R. 1999. Revisión de las abejas sin aguijón de México (Hymenoptera: Apidae: Meliponini). Folia Entomologica Mexicana 106: $1-123$.

Bego, L. R; R. Zucchi \& S. Mateus. 1991. Notas sobre a estratégia alimentar (cleptobiose) de Lestrimelitta limao Smith (Hymenoptera, Apidae, Meliponinae). Naturalia 16: 119-127.

Camargo, J. M. F. \& J. S. Moure. 1989. Duas espécies novas de Lestrimelitta Friese (Meliponinae, Apidae, Hymenoptera) da região amazônica. Boletim do Museu Paraense Emílio Goeldi, Zoologia, 5: 195-212.

Camargo, J. M. F. \& S. R. M. Pedro. 2003. Sobre as relações filogenéticas de Trichotrigona Camargo \& Moure (Hymenoptera, Apidae, Meliponini), p. 109-122. In: G. A. R. Melo \& I. Alves-dos-Santos (eds.). Apoidea Neotropica: Homenagem aos 90 Anos de Jesus Santiago Moure. Criciúma, Editora UNESC, 320 p.

Camargo, J. M. F; W. E. Kerr, \& C. R. Lopes. 1967. Morfologia externa de Melipona (Melipona) marginata Lepeletier (Hymenoptera - Apoidea). Papéis Avulsos do Departamento de Zoologia, São Paulo, 20: 229-258.

Costa, M. A.; M. A. Del Lama; G. A. R. Melo \& W. S. Sheppard. 2003. Molecular phylogeny of the stingless bees (Apidae, Apinae, Meliponini) inferred from mitochondrial 16S rDNA sequences. Apidologie 34: 72-84.

Ducke, A. 1916. Hymenoptera: Enumeração dos hymenopteros colligidos pela Commissão e Revisão das especies de abelhas do Brasil. Commissão de Linhas Telegraphicas Estrategicas de Matto Grosso ao Amazonas, Publicação no. 35, Annexo no. 5, Historia Natural, Zoologia: 1-211.

Friese, H. 1903. Neue Meliponidem II. Zeitschrift für Systematische, Hymenopterologie und Dipterologie 3: 359-361.

Friese, H. 1912. Neue afrikanische Trigona-Arten. Archiv für Naturgeschichte, Abt. A, 78: 169-170.

Friese, H. 1931. Wie können Schmarotzerbienen aus Sammelbienen entstehen? Zoologische Jahrbücher Abteilung für Systematik, Geographie und Biologie der Tiere 62: 1-14.

GeoLoc, Species Link, CRIA. Disponível em http://splink.cria.org.br/ geoloc. Acesso em: 25.I.2005.

GEOnet Names Server (GNS). Disponível em http://earth-info.nga.mil/ gns $/ \mathrm{html} /$ index.html. Acesso em 25.I.2005.

Global Gazetter. Disponível em http://www.calle.com. Acesso em: 25.X.2003

Ihering, V. H. 1902. As abelhas sociaes do Brasil e suas denominações tupis. Revista do Instituto Histórico e Geográfico de São Paulo 8: $377-388$.

Lucas-de-Oliveira, B. 1964. Descrição das rainhas de Lestrimelitta neotropicais (Hymenoptera-Apoidea). Boletim da Universidade do Paraná, Zoologia, 2: 35-49.

Lucas-de-Oliveira, B. 1968. Estádios imaturos de Lestrimelitta neotropicais (Hymenoptera-Apoidea). Boletim da Universidade Federal do Paraná, Zoologia, 3: 1-12.

Marchi, P. \& G. R. A. Melo, 2004. Notas sobre o tipo de Trigona limao Smith (Hymenoptera, Apidae, Lestrimelitta). Revista Brasileira de Entomologia 48: 379-382.
Melo, G. A. R. 2003. Notas sobre meliponíneos neotropicais, com a descrição de três novas espécies (Hymenoptera, Apidae), p. 8491. In: G. A. R. Melo \& I. Alves-dos-Santos (eds.). Apoidea Neotropica: Homenagem aos 90 Anos de Jesus Santiago Moure. Criciúma, Editora UNESC, $320 \mathrm{p}$.

Michener, C. D. 1990. Classification of the Apidae (Hymenoptera). University of Kansas Science Bulletin 54: 75-164.

Michener, C. D. 2000. The Bees of the World. Baltimore, Johns Hopkins University Press, 913 p.

Michener, C. D. \& D. W. Roubik. 1993. Observations on the labium of meliponine bees (Hymenoptera: Apidae), p. 251-265. In: T. Inoue \& S. Yamane (eds.). Evolution of Insect Societies: Comparative Sociology of Bees, Wasps and Ants. Tokyo, Hakuhin-sha Publishing Co.

Moure, J. S. 1946. Meliponas do Brasil. Chácaras e Quintais 74: $609-612$.

Moure, J. S. 1951. Nota sobre Meliponinae (Hymenoptera-Apoidea). Dusenia 2: $25-70$.

Moure, J. S. 1961. A preliminary supra-specific classification of the Old World meliponine bees (Hym., Apoidea). Studia Entomologica 4: 181-242.

Moure, J. S., P. Nogueira-Neto \& W. E. Kerr. 1958. Evolutionary problems among Meliponinae (Hymenoptera, Apidae). Proceedings of the $10^{\text {th }}$ International Congress of Entomology 2: 481-494.

Oliveira, F. F. 2002. The mesotibial spur in stingless bess: a new character for the systematics of Meliponini (Hymenoptera: Apidae). Journal of the Kansas Entomological Society 75: 194-202.

Oliveira, F. F. \& P. Marchi. 2005. Três espécies novas de Lestrimelitta Friese (Hymenoptera, Apidae) da Costa Rica, Panamá e Guiana Francesa. Revista Brasileira de Entomologia 49: no prelo.

Roubik, D. W. 1980. New species of Trigona and cleptobiotic Lestrimelitta from French Guiana (Hymenoptera: Apidae). Revista de Biologia Tropical 28: 263-269.

Roubik, D. W. 1989. Ecology and Natural History of Tropical Bees. Cambridge University Press, Cambridge, 514 p.

Sakagami, S. F. \& S. Laroca. 1963. Additional observations on the habits of the cleptobiotic stingless bees, the genus Lestrimelitta Friese (Hymenoptera, Apoidea). Journal of the Faculty of Science, Hokaido University, Series VI, Zoology, 15: 319-339.

Sakagami, S. F.; D. W. Roubik \& R. Zucchi, 1993. Ethology of the robber stingless bee, Lestrimelitta limao (Hymenoptera: Apidae). Sociobiology 21: 237-277.

Schwarz, H. F. 1932. The genus Melipona, the type genus of the Meliponidae or stingless bees. Bulletin of the American Museum of Natural History 63: 231-460, 10 pranchas.

Schwarz, H. F. 1938. The stingless bees of British Guiana and some related forms. Bulletin of the American Museum of Natural History 74: 437-518.

Schwarz, H. F. 1948. Stingless bees (Meliponidae) of the Western Hemisphere. Bulletin of American Museum of Natural History 90: 1-546.

Silveira, F. A.; G. A. R. Melo. \& E. A. B. Almeida. 2002. Abelhas Brasileiras: Sistemática e Identificação. Belo Horizonte, F. A. Silveira, $256 \mathrm{p}$.

Smith, F. 1863. Descriptions of Brazilian honey bees, belonging of the genera Melipona and Trigona. Transactions of the Entomological Society of London 11: 497-512.

Urban, D. 1967. As espécies de Thygater Holmberg, 1884. (Hymenoptera, Apoidea). Boletim da Universidade Federal do Paraná, Zoologia, 2: 178-309.

Wille, A. 1979. Phylogeny and relationships among the genera and subgenera of the stingless bees (Meliponinae) of the world. Revista de Biologia Tropical 27: 241-277.

Wille, A. 1983. Biology of the stingless bees. Annual Review of Entomology 28: 41-64

Wittmann, D.; R. Radktke; J. Zeil; G. Lübke \& W. Francke. 1990. Robber bees (Lestrimelitta limao) and their host chemical and visual cues in nest defense by Trigona (Tetragonisca) angustula (Apidae: Meliponinae). Journal of Chemical Ecology 16: 631-641.

Recebido em 22/03/2005; aceito em 27/12/2005 